International Journal of Social Science And Human Research

ISSN(print): 2644-0679, ISSN(online): 2644-0695

Volume 04 Issue 12 December 2021

DOI: $10.47191 / \mathrm{ijsshr} / \mathrm{v} 4-\mathrm{i} 12-15$, Impact factor-5.586

Page No: $3545-3567$

\title{
"Let the Children Come to Me...For unto Them, the Kingdom of God Belongs" Mk 10:13-16: The Pastoral Challenges of this Invitation in African Church Today
}

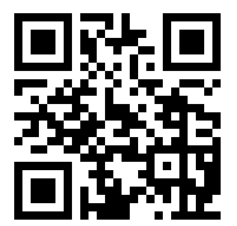

\author{
James Ekanem, SDB \\ Catholic University of Eastern Africa, Nairobi - Kenya \\ Salesian Theology College, Nairobi - Kenya \\ Veritas University, Abuja
}

\begin{abstract}
Africa is blessed with an overwhelming population of young people, who in the words of the African Synod Fathers, constitute its "numerical strength" but unfortunately, these have been kept in the cold, marginalized, exploited for selfish aims, manipulated and misled by political demagogues (Mbuy, 2001). Against this kind of backdrop the Gospel of Mark 10: 13-16 offer us a concrete, practical and pastoral way of welcoming the young people as Jesus did and giving them a sense of belonging. When I look back at some experiences I am touched by the attitude of Jesus when he said, 'let the children come to me'... and then I ask, how can the Church be available and say the same, 'let the young people come to me'? Many young people want to encounter the Lord through different forms of apostolate but maybe there are no serious youth apostolates or they are lazy to things of God or they had dreadful experiences of not being allowed to get near Jesus. Why? Perhaps, it is the attitudes of Jesus' disciples. In most of our Churches is this not the common attitude of some of our pastors? But Jesus irrespective of what and who they are said "Bring the children to me."
\end{abstract}

\section{INTRODUCTION}

Everyone in that small town by the lakeside was excited talking about Jesus, the Messiah. They had heard about him, his words and deeds. He taught about God's Love to all. This meant that God's attention was given to all and not selected few as we see happening today. Youth Apostolate is marginal in many places. Jesus was going to Jerusalem and he was stopping here in their little town attending to the needs of all both the adult and the young. People wanted to see him for various reasons. They wanted to hear his stories first hand and others wanted just to be in his presence. Perhaps when the mothers heard that Jesus was in their territory they must have stopped their cooking. Equally the fathers also must have stopped working in their fields or put down their fishing nets. Perhaps a large group of parents decided to bring their children to Jesus for blessing. When they finally reached the place where Jesus was, a dreadful thing happened. They could not get near Jesus (Just for Kids Magazine, 10 March 2008). Why? It was Jesus' disciples who stopped them. "What are you doing here with all of these children?" I guess they asked. "We come here that Jesus will bless our children," probably replied the parents. "You must go away now," insisted the disciples. "Jesus does not have time for children. He is very busy talking with important people" (Just for Kids Magazine, 10 March 2008). The parents probably must have sadly turned away, and started to leave. In most of our Churches it is a common attitude of some of our pastors barring children and youth (leave this Church, now! They will say) from experiencing the Lord. The attitude of Jesus is so edifying, "do not turn the children away" - Jesus said, "Bring the children to me." The crowd moved back to let the children through to Jesus (Just for Kids Magazine, 10 March 2008). The parents followed behind. He gently touched each one, blesses them and probably said, "I wish everyone were like children, for the Kingdom of God belongs to such as these" (cf., Mark 10:13-16). Where do we find such attitude and approach of the Church disciple today in our Churches? Do we take time with our young people? Do we meet them often or only sit in confessional boxes to wait for them?

\section{Let the Children come to me (Mk 10: 13-16)}

They were bringing children to Jesus that he might touch and bless them but the disciples rebuked them. When Jesus saw it he was indignant, and said to them, 'let the children come to me, do not stop them; for to such belongs the kingdom of God.' Truly, I say to you, whoever does not receive the kingdom of God like a child shall not enter it. And he took them in his arms and blessed them, laying his hands upon them (Mk 10:13-16). The chiastic structures of this passage lies on "let the children come to me, do not stop them, for to such belongs the kingdom of God and whoever does not receive the kingdom like a child will not enter it" (Mk 10: 14-15). This passage is about the children which immediately follow the one about marriage. It is a redactional 
"Let the Children Come to Me...For unto Them, the Kingdom of God Belongs" Mk 10:13-16: The Pastoral Challenges of this Invitation in African Church Today

construction of Mark around the saying in verse 15. They are the Kingdom (Magante, 2007). People were bringing their children to Jesus for blessing while the disciples rebuked, he said, let the children come to me (Mk 10:14). Jesus probably was not happy about that because someone was trying to treat another person badly (Cf., Mk 3: 5). Perhaps the disciples were trying to keep the younger ones away in order that Jesus takes some rest or because they did not think that it is necessary to pay attention to young people. We are aware of the fact that in the Jewish tradition women and children were not counted among the population. It could also imply that they thought Jesus was going to overthrow the Romans by force hence; it seems a waste of time for Jesus to talk to children who were too young to fight. Yet, Jesus said, do not stop them from coming to me for to such belongs the kingdom (Hargreaves, 1979).

\section{Jesus and Children}

Those who brought the children to Jesus were seeking for a blessing (Mk 10: 13) in the form of imposition of hands (Harrington, 2000). Jesus' affirmation of children with the community of God's people runs counter to biblical tradition which reflects cultural norms and patterns that marginalize the young people (Carroll, 2001). Jesus' blessing of the children furnishes an appropriate sequel to the pronouncements on the sanctity of marriage (Mk 10: 2-12). Children were brought to the Master in order to receive his blessing probably for their future life (Lane, 1974). Children in Jesus' time were persons of no importance, meriting no attention or favours (Fuellenbach, 1995) but Jesus' attitude toward children is all the more surprising. In fact, more pictures of Jesus as we see commonly have Jesus sitting with children. Jesus had a very special relationship with young people because of their innocence and their willingness to trust. It is possible that Jesus' words are meant to further encourage us his followers to be receptive to powerlessness rather than seeking power.

\section{The Face of God in Every Child}

"Within multicontext of cultures the roles assumed by children were not easily described" (Carroll, 2001). A community of faith that looks to Jesus as the human face of God will work tirelessly on behalf of this young generation (Carroll, 2001). Jesus became indignant and said, do not stop them (Mk 10: 14). They are the image of God. We should not forget to seek Christ and to recognize his presence in the young. They are true image and face of God in our families, parishes, dioceses and the whole church at large. The late Pope John Paul II told us that in our parishes, movements and communities, we should be welcoming to one another in order to build communion among ourselves. This is the visible sign of the presence of Christ in the Church, in spite of being so often blurred by human sin (John Paul II, 2004). Recognizing God in the young ones calls for full capacity to love. The more fully we can grow in our capacity to love the Christ in the young, the more fully we will be able to grow in our capacity to love all the other images of God in our world. I am convinced that the more fully we can grow in our capacity to love Christ, the more fully we will be able to grow in our capacity to take action on behalf of God's children. In fact, the more fully we can see Christ in the likes of children, the more fully we will be able to see Christ in every young person, of whatever race, ethnicity, or creed, and the more fully we will be led to offer to each young person our pledge of nurture and support. Pope Benedict XVI while receiving the traditional visit of youngsters of Italian Catholic Action, to the Vatican at Christmas, urged that the Child Jesus be recognized in all children, whom he called the "joy of the Church" and "hope of the world." He added that in the face of the little Jesus, we contemplate the face of God, which is not revealed through force or power, but in the weakness and the fragile constitution of a child. He further assures every young person that he "loves them" and has confidence in them, and that he entrusts to them "today the task of being friends and witnesses of Jesus, who came to Bethlehem to be among us" (Zenith, 2006).

\section{Children as Models and Students of the Kingdom}

A model is a conceptual and symbolic representation by which we try to understand the reality in front of us. In some sense Jesus uses it in order to clarify some issues and lack of faith (Fuellenbach, 1995). The saying of the passage treats children as symbols (Ambrozic, 1972). They are so because they are receptive and because the gift of salvation is not on merit or something which cannot be earned. They are symbol of creativeness, energy and commitment to values. Children become models because of their genuine characteristics of trust and dependency on God alone for all they need. They are equally students because of their openness and respectability of the message of the kingdom of God.

\section{2. "For onto them the Kingdom of God Belongs"}

The expression Kingdom of God appears only once in the entire Old Testament in the deuteron-canonical books. "She showed him the kingdom of God and taught him the knowledge of holy things Wis 10: 10" (Fuellenbach, 1995) but in the New Testament the kingdom of God is a key concept attributed to Jesus in the Gospels and occurs many times which refers to the reign or sovereignty of God over all things in contrast to the reign of earthly powers. Jesus never defined the kingdom of God. He only described it in parables and similes (Cf., Mt 13; Mk 4) but the kingdom of God was Jesus' special way of speaking of God's purpose for us though it was not widely used during his time. This idea occurs predominantly in the synoptic gospels. 
"Let the Children Come to Me...For unto Them, the Kingdom of God Belongs" Mk 10:13-16: The Pastoral Challenges of this Invitation in African Church Today

\section{The Kingdom is a Gift and Characteristics of Children}

John Hargreaves says that "to receive the kingdom is the same thing as to "enter the kingdom" (Mk 9: 47); "to enter into life" (Mk 9: 43); "to be saved" (Mk 10: 26). All these mean "living the best and most joyful kind of life" (Hargreaves, 1979). According to Aloysius, the gospel of Mark still look forward to a fulfillment of which the present experience is but a foretaste of a life to come. Yet this foretaste participates in the character of the future kingdom. The mystery of the kingdom is a present gift (Ambrozic, 1972). Jesus is the kingdom. His invitation 'let the children come to me' is calling us into his kingdom present. It is a gift which goes beyond any barriers as the disciples did to the children. Jesus calls us to dispose ourselves like the children. Jesus emphasis is about the kingdom as unmerited and gracious gift from God, who comes with unconditional love to seek out his children and to offer them the ultimate salvation. In fact, it is a gift from God which we can only receive in gratitude and awe. In this gift God comes toward us as unconditional love, seeking communion and intimacy (Fuellenbach, 1995).

"The child as metaphor for the relation of the people to their God is obviously a relational term, but it is not age specific. Surely, it points to such qualities as dependence upon God, reliance upon divine protection, and assurance of divine care and love" (Carroll, 2001). The gospel mentions about receiving the kingdom like a child (Mk 10: 15). The chief characteristic of children is receptivity. The kingdom must be received as a gift. Jesus urges us to be childlike to enter the kingdom of God. The characteristics required are that of simplicity, unpretentiousness and willingness to trust. These are the qualities associated to winning the kingdom of God. Trust is a firm reliance on the integrity, ability, or character of a person. It is a condition of having confidence placed in one - the person of Jesus Christ. Why is the kingdom belonging to such as these? Christophe Potworowski says that the "attitude of welcoming a child (Cf., Mt 18: 5) is not some peripheral duty imposed on Christians as in a program of social welfare but it points rather to something which is central in Christianity (Potworowski, 1995). Hence, the characteristic of children is such openness and simplicity of heart. They have unpretentious attitude and willingness to trust. So they are trustful and dependent on God. This kind of virtue earns them the kingdom. As such we are all called to display this kind of virtue in order to gain the kingdom of God. Jesus' coming to us is enough reason to get hold of him. He is the kingdom among us (Kilgallen, 1989).

\section{The Kingdom is not Reserve of any Privileged Group}

We see the disciples, in seeking to send the children away, have not just made a small error in judgment. They have shown that they are missing the whole point about Jesus' ministry. For Jesus' ministry is precisely about welcoming ones such as the powerless, the vulnerable, the weak, those often considered a nuisance. Jesus' ministry is about bringing everyone in, and not at all about keeping some out. "The necessity of a childlike attitude in order to receive the kingdom of God thus requires a reawakening of our true origins, a conversion" (Potworowski, 1995. The text in the gospel speaks not of the coming of the kingdom of God as a future event in some places, other places as an ongoing or even a completed event but the kingdom as present. The gospel says whoever does receive the kingdom of God like a child (Mk 10: 15). This saying clarifies the latter part showing that only those who accept the kingdom as a gift can expect to enter it Mk 10: 14 (Harrington, 2000). As a matter of fact, it is only those who recognize and receive it as a gift can expect to be part of the kingdom of God (Harrington, 2000). Jesus is the kingdom and he is inviting all. The kingdom "belongs" to the young in heart in the sense that they are the ones whose dispositions appreciate a gift as an absolute, something which they are aware they cannot have worked to deserve (Fuellenbach, 1995). We can have this kind of life (as gift from God) by being like children. To receive the kingdom requires child-like disposition and nothing else. The kingdom is not reserve for privilege people. It cannot be bought. It is for the simple of heart and for those who open themselves up to enter into covenantal relationship with God (Hargreaves, 1979). The kingdom is not preserve for privilege group but for the simple of heart such as the young people. "By promising the kingdom to children Jesus challenged contemporary theological thinking on merit, reward... Being "like a child" means one has nothing to give, nothing to show, in order to gain the kingdom" (Fuellenbach, 1995).

\section{Invitation to follow Christ's Model}

When finally the disciples step aside and allow the children to be brought forward to Jesus, he did not just touch them briefly and then send them on their way. No, Jesus warmly embraces them and then places his hand on their heads in blessing. What comes clear in this scene is that Jesus actually loves them. And he furthermore understands that his relationship to children is not tangential to his ministry but quite central to it. Therefore as Christ's followers and more precise shepherds of God's flock we have a model before us to imitate and emulate the examples of Jesus himself.

\section{Open Approach and Dialogue}

Jesus took the children in his arms and blessed them (Mk 10: 16). He demonstrated how we should treat the less privilege youth of our parish and society. Jesus shows gesture of loving acceptance and generously blessing them. Jesus' open approach gives the young ones confidence in him and because of that they were open to dialogue. Thus, we are asked to abandon false values such as status seeking, power, and wealth and not to embrace these values of an unauthentic being and serve as barriers to entering the kingdom of God (Fuellenbach, 1995). Jesus is saying that children need to be welcome and to be offered the reign of God's love. They must be listened to with love and understanding (Fallon, 1995). A dialogue is a reciprocal conversation between two or more 


\section{"Let the Children Come to Me...For unto Them, the Kingdom of God Belongs" Mk 10:13-16: The Pastoral Challenges of this Invitation in African Church Today}

persons. It is an exchange of opinion. Martin Buber in his philosophy considers dialogue as an effective means of on-going communication rather than as a purposive attempt to reach some conclusion or to express some viewpoints. People engage in dialogue in order to explore their assumptions of thinking, meaning, communication, and social effects. Jesus enters into dialogue with all of us so that we may assume the true children of God and communion through him. Today, dialogue is used in classrooms, communities, corporations, agencies, and other settings to enable people, usually in small groups, to share their perspectives and experiences about some issues. It is used to help people resolve long-standing conflicts and to build deeper understanding of contentious issues. The gospel shows a kind of relation between Jesus and the young people but the portrayal of the disciples is that of a resistance which anticipates the reluctance of some of his followers across the years and in many parts of the world not excluding Africa (Carroll, 2001). Dialogue is not about judging or making decisions, but about understanding and learning. It dispels stereotypes. It builds trust, and enables people to be open to perspectives that are very different from their own. This is exactly the invitation Christ is challenging us to undertake - a challenge to engage young people (Pastores Dabo Vobis, 8) in dialogue.

\section{Descending Method}

"The attitude of Jesus towards children, as recounted in the Gospels, shows a shift in the values of childhood in relation to previous conceptions. It is no longer seen as a stage on the way to the fullness of humanity, a stage to be out grown and left behind, but as a value in itself" (Potworowski, 1995). Here we see Jesus reminding the adults not to stop the children (cf., Mk 10: 13-16). So Jesus, full of grace and mercy, is willing to set and enforce safe boundaries, to rebuke the disciples. Jesus bends down and is talking to the children at their own level. Have we ever thought about ourselves from a children's perspective? We are so much more powerful and much stronger yet Jesus chooses to humble himself, to get down to children's level. Would it not be fitting to all of us, as Church leaders in Africa do that with every youth in our midst and churches? We know that young people are so much more vulnerable than us. In Jesus' day, they were nothing. They were simply the property of parents. But Jesus took it differently. To Jesus they are actually signs of the Kingdom. Imagine taking that literally, that every child we know is a sign pointing us to God's Kingdom. Jesus is changing understandings of ownership. Children are not the property but are signs of the Kingdom. Jesus descended down to embrace and probably listens to the young ones. This is not just a warm end to the story but an invitation to do the same. How much have we as pastors and parents gone down, take time to listen to all the young ones in our parishes? Jesus going down for the young does not remove his Godly or glory nor does it take away any authority or power from him. In fact this descending method enables the young ones to enter the kingdom. The gesture displayed here teaches us in action what the words of Jesus want to convey. And that is, the kingdom is for those who like children make their way to Jesus. And Jesus coming down to them makes them become free and open up to welcome Jesus (Kilgallen, 1989). As a Church and pastors we have to follow Jesus' example of coming down to the level of the young ones in order to help them embrace the gospel values, teachings of the Church and the Eucharist rather than staying up there to rebuke and complain about the youth of the parish.

It is true the gospel passage of Mark with which I begin to reflect specifically speaks about children. Children in that context are not mentioned of their age though today a child is considered a person between $18^{\text {th }}$ months and 13 years of age but strictly speaking a child is anyone who is not yet an adult and thus we can refer it to young people. In this reflective exercise with regard to the choice of the topic and contents we shall be talking of children as the young people or the youth. As such where ever children are mention it refers to the young people. To be more specific in this work, children imply young people. "The future, joy and hope of any family, community, society, state or continent and the Church lie in a well-prepared and responsible young generation" (Mbuy, 1996). The gospel passage of Mark 10: 13-16 draws the Church attention to the person of Jesus Christ and his attitude: openness, dialogue and humility toward the younger generation. The passage also highlights Jesus' understanding of children as the image of God and models of the kingdom. It touches the fact that the kingdom of God is an unmerited and gracious gift which is not reserved for any privilege group of people but for all. Jesus has given us an example to follow in the answering to the signs of time we need youth ministry in our parishes. On a practical note when we look at our parishes or diocesan set ups it seems the young people have been subjected to noisy spectators with little or no say decisions that concern them. I mean the church in a parish or diocesan set ups where youth ministry has not yet been established. As a Church we are invited in this time to draw up programs and models that will draw them to the Church (Jesus Christ) and daily experience of their growing faith and life in Christ. Hence this gospel passage of Mark 10: 13-16 is significant today because it serve as a resource material to assist us in making a step toward listening to the needs and concerns of our young people as Jesus did (Mbuy, 1996).

\section{Pastoral Challenges of Christ's Invitation in the African Church Today}

In the gospels there are three groups of sayings that relate children to the kingdom. The first group says that the "kingdom belongs to them" (Mt 19: 14; Mk 10: 13-16; Lk 18: 17); the second group states that only "in becoming like children can one enter the kingdom" (Mt 18: 3); and the third group explains that anyone who receives a child receives Christ himself Mt 18: 5; Mk 9: 37; Lk 18: 17 (Fuellenbach, 1995). Children seem to be at the centre of Jesus' ministry as we have seen in the previous chapter. His approach to them is amazing. As a Church we have receive the mission mandate to assume the role of a shepherd to all Christ's 


\section{"Let the Children Come to Me...For unto Them, the Kingdom of God Belongs" Mk 10:13-16: The Pastoral Challenges of this Invitation in African Church Today}

faithful including the young. "The Church as the community of those who have been chosen to carry on the vision that Jesus conveyed must define itself in relation to the kingdom, which is meant for humankind and the whole of creation. Its mission is to reveal through the ages the hidden plan of God (Eph 3: 3-11; Col 1: 26) and to lead humankind toward its final destiny" (Fuellenbach, 1995). Hence, Jesus' acceptance of them and the embrace pose a challenge and summons the Church in Africa to an honest self - examination of its pastoral care of the youth ministry (Carroll, 2001). Let me share with you why I have commented time and energy to the subject of pastoral challenges with the youth. The experiences that led me to reflect on this subject matter which is a great concern for the Church of our time. I appreciate Saint John Bosco who is a gift to the church and to the young people that through him I have become and inspired to be present among the youth. I recall years I have been serving in the parishes as altar server, as cook, and etc. My experience of the reality of the youth is like they have no place. I appreciate few parishes and dioceses who have taken as priority the formation of the youth in their parishes and dioceses. Later in the years past, moving from one parish to the other on pastoral assignments, seminars, workshops, retreats and recollections I have seen and witness the experiences our young people are going through. Everyone in the society and even in the Church seems to be at a distance, complaining here and then the behaviour of the youth. We so much talk of structures of faith rather than formation of faith. We fail to share in the pilgrimage of our young people, hence when they are faced with crisis and confusion they have no church to go than seek other means they consider helpful to them. This chapter shall envision the challenges we experience as a Church in Africa and what could be an answer to a sound and effective pastoral care for the young people. They deserve pastoral care and attention in all our parishes. Therefore as a Church and as pastors the signs of time challenge us and we have to give answer to it. When the young people went to Jesus he gave them answers to their concern. Are the Church ready to welcome these youth of our time? (Lester, 1985).

\section{Presence of Children and Youth in the Church}

Pope John Paul II was a man of great attraction to young people. The world youth day for him became an occasion to gather young people to give them an opportunity to ponder on their life's deepest questions and to offer them concrete and serious answers. He always urged the young people to reject hedonism and materialism, defend human life, and embrace suffering for the sake of the truth. This was a man who laid down a legacy in the life of many young people. The presence of children and youth in the Church is a blessing to the Church as well as the family and the society at large. Any Church and family that care about its future must be ready to prepare its young generation. More and more I am drawn toward the picture of young people around Jesus in the person of the Pope. The purpose of the world youth days which is a coming together of young people from all over the world as one people, one family and a strong reminder of the strength and confidence the young people bring to the Catholic Church today. It is not simply a gathering for the young people of the world, but a time to put trust in the world's youth. In Africa and may be elsewhere in the world the young people are asking the Church a fundamental question: where shall we go (Cf., Jn 6: 68)? Our Holy Father John Paul II answers the longing of the young people as follows,

I long to see you, that I may impart to you some spiritual gift to strengthen you, that is, that we may be mutually encouraged by each other's faith, both yours and mine" (Rom 1:11 - 12). Indeed, I come in spirit to you with this same wish, to meet you in every corner of the earth, wherever you face the intense, daily adventure of life: in your families, where you study or work, in the communities where you gather to hear the word of the Lord and to open your hearts to him in prayer. My gaze turns in particular to the young people who are personally involved in too many of the tragedies that still wound humanity: those suffering from war, from violence, from hunger and poverty, and from the burden of pain and injustice (John Paul II, 1996).

Such a beautiful disposition where can we find in some of our Parishes or Dioceses? For some of our parishes and dioceses the World Youth Day come and gone without any mention of it. We seem not comfortable to gather young people around us. Jesus is a model for mature faith in action and, more specifically, for faithful, effective ministry. Hence we must learn what values he places on the young people when he says, let the children come to me (Mk 10: 14) and where they fit in his ministry (Lester, 1985). The presence of the youth is a blessing to the Church. Jesus is telling us, "do not rebuke them," but invites them to share in the life of the Church.

\section{Young People in the Growing Consumerist Society}

Consumerism is the myth that the individual will be gratified and integrated by consuming. We are living in an era of great changes where humanity often finds itself uncertain, bewildered and anxious (Cf. Mt 9:36). The church in this growing consumerist culture is challenge especially in the way our young people are engrossed in it. Raising Christian children in such a secular and consumerist world is rather not easy but we need not give up our attention to them. From the interviews and questionnaires $80 \%$ of priests, religious and the laity affirm that consumerism has led to the decline in spiritual life of the youth. It makes them become self-centered and the dignity of personhood forgotten. Only very few young people show comment on the same line. The desire to have has gone out of control. The goods of the world fall more and more into the hands of those who have more rather than into the lives of those who desperately need them. Such consumerism creates the false polarity of bloated, over-saturation and emaciating 


\section{"Let the Children Come to Me...For unto Them, the Kingdom of God Belongs" Mk 10:13-16: The Pastoral Challenges of this Invitation in African Church Today}

poverty. The Holy Father in his Apostolic Exhortation on the formation of priests states the problem of young people in these words: "The lure of the so-called 'consumer society' is so strong among young people that they become totally dominated and imprisoned by an individualistic, materialistic, and hedonistic interpretation of human existence" (Patores Dabo Vobis, 1992). In fact, adaptation of modern customs, culture and habits at the expense of discarding the traditional institution values is presented as the result of changing attitudes. We are challenge when the traditional cultural values of society are degenerating under the influences of corporate politics and commercialization of culture. Society is often stripped of tradition and controlled by an oppressive power structure. However, in conversion with some they said their encounter with the welcoming Church and priests like the Holy Father during world youth days change their attitudes and outlook in life. Some gave up obsessive quest for pleasure that had led them into promiscuity and rabid consumerism. Others discovered a passion for pro-life activism or service to the poor and many returned to the sacraments. Just like Jesus embraced the children, the Holy Father opened up taking upon himself the descending approach to young ones. In this consumerist culture the Church and her pastors are challenge and as such pastors have a bigger role to play in dealing with the young people. The attitude sometimes display is amazing. We sometimes wonder; does the Church really care for the young?

\section{Family Disintegration and Young People's Crisis of Faith}

Let the children come to me (Mk 10:14) Jesus invites all as God's family where all are welcomed. Family plays a very important role in building up society and the Church. Today, there are so much heard of family disintegration (Durka, 1988). Contemporary African families have been subjected to just "me and my family," without having anything to do with the extended family. The best environment for a child to grow and mature is the family. Yet, common to all is a growing tendency towards family fragmentation and disintegration. During my interviews $75 \%$ of priests, religious, youth and laity together affirmed that many families disintegrated because of various reasons and have become a challenge to our young people. They cited samples of no proper understanding of marriage commitment, changes in the West in cultural values and emphasis on the new individualism undermine marriages and commitment resulting to divorce, out of wedlock births, single parenting and careerism (leading to poor quality child care) is in the height, poverty or deteriorating economic conditions and insufficient welfare support undermine family life. It also emerge that in many cultures migration to urban areas and political ideologies and work ethics often wage war against the family. Conflict and war, natural disaster or ill health does also have devastating effects on the family and children are separated from one or both parents or tragically orphaned.

We cannot talk about the family without touching on these problems most disturbing and cause the Church concern: cohabitation of couples, same sex marriages, single and surrogate parenthood. The state cannot be prevented from responding to new situations present in society, from recognizing some civil rights of persons, even of the same sex, who have decided to live together. In fact, the essential thing is marriages as God plan, good family and society and the upbringing of the younger generation (Zenith, 2006). When families separate, divorce and single parenthood, who nurtures and supports the young born in such families? Assuming the parents of these families passed away the children are left on themselves. No other family member could take care of them. Most experiences I have witnessed it is the Good Samaritan who would say, 'let them come and stay with me' otherwise the greater number are on the street (Pendawazima, 1999). Father Cantalamessa says that the family is of primary importance among the many areas. It is a true community of discipleship and the true school of social life where the youth grow (Zenith, 2007).

Every young person is a gift and God's blessing to the family (Gen 13: 16; 15:1-6; Ps 127: 3-5). Young people then embody the hope of the family, or the people, for a meaningful future (John Carroll, 124). Young people represent the divine blessing and they are the bearers of a family and of the future. We the Catholic Church have always believed that Christian marriage is an indissoluble union of one man and one woman until death. Much of what we see today in Africa is largely attributed to family breakdown. Archbishop Silvano Tomasi C.S., Holy See Permanent Observer to the United Nation on March $23^{\text {rd }} 2007$ calls for protection and promotion of family life. He says that the "first right of children is that of being born and educated in a welcoming and secure family environment where their physical, psychological and spiritual growth is guaranteed, their potential is developed and where the awareness of personal dignity becomes the base for relating to others and for confronting the future" (Pope Benedict XVI, 2007). Jesus invited the young people that he may share with them the love, concern and beauty of a family (Ekanem, 2009). The Church need to invest in family formation so that parents as well as the youth can better assimilate the Church teaching and be ready to face modern challenges of family life with hope and love.

Crisis of faith is another area that poses challenge to our pastoral ministry. Crisis is a situation that is unexpected but poses certain grave challenges especially in the young people. There are three strong forces that today have caught many in the cross road. Christian values on the strict adherence to rules with it aims in everlasting happiness in the world to come. The Western culture and its expanding scientific and technology have exposed them to enjoyment of life to the maximum. They believe they are presenting the fullness of life for the kingdom here and now while the African culture and values keep biting hard on the conscience of many young people in spite of their effort to through it off (Mbaegbu, 2003). About 70\% of young people said their peers face crisis from uncontrolled exposure to mass media, scandals of Church leaders. $60 \%$ of the priests, religious and the laity said that crisis do also 


\section{"Let the Children Come to Me...For unto Them, the Kingdom of God Belongs" Mk 10:13-16: The Pastoral Challenges of this Invitation in African Church Today}

arises from the ill-treatment of youth in the Church, lack of participation in faith and Church matters. They also say it is because of lack of accompaniment of the youth and faith catechesis. We have to admit that there is a crisis of faith in the Church. We may say they have unqualified faith of Catholic Christianity but for sure to these young people who wander in our parishes without a shepherd the little faith they have is going to be weakened and for some they will lose it. Once, I was shocked when a young girl after sharing her experience with me said, "Bro, where do I fit? I am rejected by my family, society and even the Church I had my last hope rejected me". For her it was like everyone has cast her out. To this young girl I suppose have come to Jesus what would Jesus do? Would he say cast the stone on her, stone her to death as the law prescribed? The concern expressed by young people reflects new social worries as well as typical youth struggles. Dating, sexuality, tensions with parents, elders and pastors continue to strive as they try to find their own identity and struggle for independence by testing the limits and challenging rules (Rowatt, 2001).

Crisis of faith is a critical period in the young's lives. They become uncertain about what as Catholics they are to hold. And as a result they are emotionally insecure, bewildered and, in Christ's words, wandering as sheep without a shepherd. In reality, many teens ordinarily find their lives frustrating and disappointing. The Hollywood portrayal of teenage fun, fame, and friendships eludes them, and they experience depression, isolation, confusion, grief, anxiety, rejection, anger, and loneliness. They feel betrayed when their aspirations turn into terrifying reality. They have been through many things. A romantic evening and relationships turns into a pregnancy or someone special dies, infidelity of parents, trusted friendships turns sour, cases of abortion, violence and dreams become nightmares. For many of us we long to feel young again though we frequently resist dealing with issues of the youth. To these young people Jesus invites them. Let them come to me (Rowatt, 2001). Life is not a rose garden for many youth as it is to any other adult. In most instances our young people (Martin, 2018). experiences absence of their pastor in times they needed them most. Some said their pastor never come by. Then I wonder - where were the pastors? (Lester, 1985). Do you want to know the needs of these young people? (Martin, 2018). They need sense of competence from us. When they are included in the process of confronting and responding to the challenge posed by the crisis, then their sense of competence will be equally and greatly enhance. They need confirmation of their perceptions. Confirming what they perceive "does not mean" (Martin, 2018) accepting but helping them to shape and deal with those perceptions and being "close to them" (Martin, 2018) in such critical moments (Lester, 1985). They need someone to listen to their stories and experiences. They need someone who listens without judgment and someone they are free to talk to. They need someone to accept them. They need spiritual guidance (Lester, 1985). They also need to feel the sense of belonging and pastors should give them such room in accompanying them to mould their sense of belonging. Authoritative presence will do quite opposite but rather creative and educative presence brings them delight as they take some responsibilities in the Church. Through the youth ministry they learn to cultivate the sense of community at heart. Once this is achieved we don't waste energy and time looking for "where the young people are in order to" (Martin, 2018) give them something to do. They will always be there and from time to time would be asking us what is to be done (Lester, 1985). Above all there is a need for catechesis and giving them the opportunities to experience various sacraments and be available for their spiritual direction.

\section{The Challenge of Youth-unemployment}

"There is an ongoing debate about the position of young people in the society and their access to resources" (Banks, 1999). I enquire this among four groups of people: priests, religious, laity and the youth. All of them about $65 \%$ says unemployment of youth cause many challenges. $15 \%$ says that there is enough work but the youth are lazy while $7 \%$ would not comment on this and $3 \%$ says the youth search for jobs and forget their spiritual needs. As the family structures breakdown many youth seeks to be in the urban areas than rural home in the name of searching for jobs and employments. The young people face tremendous problems in contemporary times with no enough job opportunities. Unemployment and lack of educational opportunities are problems especially in rural areas. For example, the proportion of socially excluded, unemployed young men and women is relatively high. Indeed, enormous numbers of young people are moving into towns. Some become domestic workers. Some are exploited with all the consequences of such situation. It has become an opportunity for many of them for unproductive activities. For other their bosses have taken advantage of them as they move away from home to seek employment in the cities. We can equally sense danger as young people are no longer active in the traditional and Church matters. Many are active in sports clubs or hobby groups. Who will speak for and to them? Who makes certain that their concerns are addressed in "our Church and the world" at large? (Martin, 2018 and Devries, 2001). The plenary meeting of Amecea Bishops in 2002 stated: "We encourage the creation of more technical/vocational institutions in the Region in order to respond, at least partially, to the huge problem of unemployment among the youth." "In realization to these good statements, what we see are fragmented individual initiatives that last as long as the individual last... There is the absence of a clear strategic focus on this group" (Mondo, 2006). Is there any ministry in the Church that could address this matter? Every Sunday we have our faithful in front of us can we identify any of the young people in similar circumstances and say, 'come my child, what is your problem? (Moschetti, 19-20).

Many young people feel that the Church is not doing much to assist them in this area (Martin, 2018). However the Church with all it says in the social teaching seems to have failed to cater for the socio - economic life of its youth. Reality shows more and more that it is impossible to evangelize the hungry unless they are first fed, 'give them something to eat.' If we are not ready to feed 


\section{"Let the Children Come to Me...For unto Them, the Kingdom of God Belongs" Mk 10:13-16: The Pastoral Challenges of this Invitation in African Church Today}

this young generation we may lose out in matters of faith and morals (Mbuy, 1996). The current cultural and political struggles over young people will seem to continue. The landscape may not help but changed if the Church in Africa reclaims the radical message of Jesus' teaching about welcoming the young to an experience of the Lord (Devries, 2001). In the Gospels, Jesus points to young people as pattern and paradigm of God's reign. Challenged by Jesus' counter-cultural affirmation of the young, Christian communities are called to vigorous and insistent advocacy for young people in our time (Carroll, 2001). We have to face the challenges of encouraging young people to find a direction in their lives and view all the options to help them to go out into the world (Martin, 2018) and at the same time, to prevent them from becoming socially excluded. We have the obligation to help them face their problems and help them to look forward, even when things do not look so bright.

\section{Alienation of Youth from the Church, Rigid Doctrines and Cold Liturgies}

In the gospel, the disciples barred the young people access to Jesus touching and blessing them. Alienation of youth from the Church (Martin, 2018) perhaps, may be traced to some attitudes in the Church. Do our Church, perhaps in its pastors and Christians play a similar role like those disciples? (Carroll, 2001). It is our duty then to live in history, side by side with our young people, sharing their worries and hopes because we must be fully people of our time. We cannot escape into another dimension, ignoring the tragedies of our era, closing our eyes and heart to the anguish that pervades life. On the contrary, it is he who, although not 'of' this world, is immersed 'in' this world every day, ready to hasten to wherever there is a brother or sister in need of help, a tear to be dried, a request for help to be answered (John Paul II, 1996). They alienate themselves from the Church because we have failed in many occasions to attend to them though pointed out this few areas.

$55 \%$ of priests and $70 \%$ religious say that there are simplified literatures for the youth while $80 \%$ of the laity says this yahoo.com generation doesn't want to obey. They simply want their way. They don't want to listen and the rules. About $70 \%$ of the youth says the Church rules are too rigid and most of their ministers do not take time to explain to them and in most cases they will over-react when the question of why is addressed to them. I picked up some examples from the youth. Many youth (like young adult 25-35) feel they are lost generation. They so often leave the Church because of living with partner out of wedlock, with a feeling of accused from every side: family, society and the Church since they had not their marriage blessed in the Church and so cannot receive the sacraments. They consider it rigid because not much is done in helping the young to assimilate each doctrine as one growing in faith (Martin, 2018). This poses challenges to the Church on how to deal with its young generation (Martin, 2018) who has thousands of questions to ask. In some places to have a chance to go for confession one must pay all his or her Church dues. Going for confession you need to be certifies that you have no due to pay. It is not only in this areas even visit to the sick and other Church benefit each member should receive. Where is the Church ministry to these brothers and sisters of mine? "Whatever you do to these you do it to me" (Whelan, 2006). I feel and believe that the occasion of the world youth day is the best and better opportunity where some of the doctrines could be put in a platform whereby we dialogue with the young people and explain to them. Such step could not only wait for world youth day but also at the diocesan and parish levels. Jesus points to the young as pattern and paradigm of the kingdom of God. In fact, God's household is not governed by the prevailing patriarchal norms, and there is a place, a central position of honour for the younger ones in the Church and those lowest in status and power. Given all that is happening, many young people are not rejecting the faith or in serious doubt about Catholic doctrine, but they are bewildered of the rigidity of it. Many are bewildered and are confused, distraught, perplexed, and worried and some are caught up in an interior convulsion of spirit that has rocked all of Christendom to its foundations (Carroll, 2001).

Cold liturgies are another concern as to what alienate the young people from the church. Why in a given parish the youth which is half the population of the faithful are passive in liturgy? Dennis Geaney says that one of his roles as a parish priest is liturgical greeter. At the weekend liturgies he will go up and down the aisles before each mass playing the jester or clown, warming up the people for a joyful celebration of the Eucharist. He would play with the children, youth and as well interact with the elderly people before the celebration. According to him the over-all goal is to pull people into a feeling of relatedness. He tries to break the barriers of individualistic piety and get people out of their self-centeredness into the Body of Christ. By smiles, laughter, and a few caring words, he try to bring people from the private commerce with God into a worshipping community (Geaney, 1987). Here is my finding in this regard. About $75 \%$ of youth say that the liturgy is not lively. They say they have not experience so far anything of inculturation hence, many youth prefer to other places where the liturgy is lively and they don't mind traveling some distance as long as they get the taste of the liturgy they want. For the young people the celebrant matters the most in the celebration. He should be one who calls the young people to active, full and conscious participation. Young people believe in lively liturgy. If the pastor is cold definitely that liturgy will be cold. However, making it lively is not in any way reducing it to entertainment parks. Youth liturgy has to be different from the adult stuff as well as children liturgy.

\section{Youth and Liturgy from the Catholic Point of View}

"This sacred Council has several aims in view: it desires to impart an ever increasing vigor to the Christian life of the faithful; to adapt more suitably to the needs of our own times those institutions which are subject to change; to foster whatever can promote union among all who believe in Christ; to strengthen whatever can help to call the whole of mankind into the household of 
"Let the Children Come to Me...For unto Them, the Kingdom of God Belongs" Mk 10:13-16: The Pastoral Challenges of this Invitation in African Church Today

the Church" (Sacrosanctum Concilium, 1). "The liturgy daily builds up those who are within into a holy temple of the Lord, into a dwelling place for God in the Spirit" (Sacrosanctum Concilium, 2). "The liturgy is the summit toward which the activity of the Church is directed; at the same time it is the font from which all her power flows. For the aim and object of apostolic works is that all who are made sons of God by faith and baptism should come together to praise God in the midst of His Church, to take part in the sacrifice, and to eat the Lord's supper" (Sacrosanctum Concilium, 10). These are statements according to Robert Martin that have to be translated into action the kind of liturgy that answers the 'needs' (Martin, 2018) of people and foster active participation.

Parents are deeply concerned about their children not enjoying the church while others seem it's alright for them as long as it does not interfere with their life. In many cases they throw their hands up in total frustration and despair, or they place the responsibility and hopes for their children on the parish religious education director or the youth minister (Singer-Towns, 2016). Many people feel that priest should develop catechetical programmes in the parish to assist these young people but I am also worried about the same parents who propose this, yet they are the first who immediately after mass tell their children, "come let us go home." Some of them would not even allow their children to step out for any activities organize in the parish since they are not there with them. Again, I also wonder if our liturgy is helpful to our young people. Is the present way our worships is design really helpful to our young people? Or does it rule out contemporary forms of liturgy that is accessible to the young people? What about the length of the homily and the worship itself? It is important to underline certain things in the liturgical celebration of the Mass. Let us begin with the introductory rite. This part becomes so and extremely long without any bearing on the lived experience of the faithful. The impression created make the young people lose focus right from the very start of the celebration. In the liturgy of the word in some parishes the priest does not allow liturgical dance owing the fact that it's more like dancing in the disco hall. One wonders how many times the priest take time to explain the liturgy and liturgical dance to these youth. Homily is another thing. During homily we have to be aware that it is a homily. We should not moralize the homily and should be brief and probably use helpful stories (Singer-Towns, 2016). During liturgy of the Eucharist complain on the side of the young is not much except in the area of the offertory. In some parishes the way this is done seems humiliating to youth especially when they have no money to offer and it's a must one has to stand up and go to offer. On the other side the faithful in Africa would want to express themselves but they are not allowed to do so. There are policies probably the priest does not see meaning in such expression as the faithful do. In the concluding rite the issue of announcement makes the faithful especially the youth impatient. You see some of them moving out one by one without the final blessing. Above all one constantly hear people talk after Mass; 'today the mass was dry,' 'the priest had nothing to say,' what was he say?' We have to sincerely bring all these into scrutiny to make the liturgy lively and must have bearing in the life of people (Carroll, 2001). The Church has no wish to impose a rigid uniformity in matters which do not implicate the faith or the good of the whole community; rather does she respect and foster the genius and talents of the various races and peoples. Anything in these peoples' way of life which is not indissolubly bound up with superstition and error she studies with sympathy and, if possible, preserves intact. Sometimes in fact she admits such things into the liturgy itself, so long as they harmonize with its true and authentic spirit (Sacrosanctum Concilium, 37). This is the longing of our young people (Martin, 2018) that space is given for inculturation which could bring in a youthful and lively liturgy.

\section{Taking Active Participation}

The Church earnestly desires that all the faithful be led to that full, conscious, and active participation in liturgical celebrations called for by the very nature of the liturgy. This full and active participation by all the people is the aim to be considered before all else; for it is the primary and indispensable source from which the faithful are to derive the true Christian spirit; and therefore pastors of souls must zealously strive to achieve it, by means of the necessary instruction, in all their pastoral work. Such participation by the Christian people as "a chosen race, a royal priesthood, a holy nation, God's own people" (1 Pt 2:9; see 2:4-5) is their right and duty by reason of their baptism. In the reform and promotion of the liturgy, this full and active participation by all the people is the aim to be considered before all else (Sacrosanctum Concilium, 14).

There is a concern that many young people go to Church because their parents go or they are forced to do so or school time-table oblige them. From my interviews about $57 \%$ of youth say that majority of them are passive in the Church because of feeling of rejection, they have lost meaning of Mass and no youth liturgy. About $28 \%$ of the priests, religious and the laity say it is because the youth are considered recipients and no place for them while $15 \%$ of all the groups do not know the reason they are passive. Garry L. Chamberlain observed that "participation is an outgrowth of our very understanding of the human person" (Chamberlain, 1988). The youth have continued to be more observers with most liturgical worships addressing God with symbols and languages sometimes they do not understand (Mbaegbu, 2003). For the young people the Church life in parishes seems so centred upon the adult needs and many young people do not feel a part of the life of the Church (Martin, 2018). Hence the sense of involvement and participation in the life of the Church (Martin, 2018) becomes critical. And probably nothing brings a greater sense of alienation to them than the anguished realization that there is no place for them. It is a painful exclusion (Chamberlain, 1988). To promote active participation, the people should be encouraged to take part by means of acclamations, responses, psalmody, 
"Let the Children Come to Me...For unto Them, the Kingdom of God Belongs" Mk 10:13-16: The Pastoral Challenges of this Invitation in African Church Today

antiphons, and songs, as well as by actions, gestures, and bodily attitudes. And at the proper times all should observe a reverent silence (Sacrosanctum Concilium, 30). All these they do as duty and not as responsibility. Adding flesh to what they do is lacking. They need catechesis to accompany their experiences of the Church's life.

\section{Decline in Sacramental life and Lack of Catechesis in Faith Growth}

There are several reasons many of our young people decline from the sacrament of penance. These are the findings in my interviews. The modern world today has lost the sense of sin due to more scientific and technologies which orient human being towards extreme materialism. Many people seems comfortable with the public general confessions as the protestants do than confess to a priest. To other there is lack of priests. Others have difficulties in confessing their sins. To some they have lost confidence in their priests as part of their homilies seems what they listened to, at confession. One young person (name withheld) lost confidence on the whole idea of confession to a priest. He is a businessman. He moves from one town to another. He once went for confession and on his business trip to another town that priest was invited to celebrate there and he was there at the celebration. The young man said the priest's homily was on the subject of his confession he made without, knowing the young man was in that celebration. Another boy told me, bro. I will never go for confession to that Priest. Then I ask why? He told me each time the priest sees him he asks him, 'have you changed.' For the priest it might not refer to confessional seal but for this young boy that is his feeling. The Code of Canon Law is very clear on this matter of breaking of confessional seal through indirect sharing and homily (Code of the Canon Law, 1983, Nos. 983 and 984). To others they have forgotten the formula while some don't like the formula at all. For others to have such chances to receive the sacrament you must pay all your dues in the Church. Jesus says, let them come. Jesus lacks nothing of catechesis for them. In fact, we should not be surprise in some places there is no more catechesis for the youth. The only chance was only when they were preparing for Baptism (adult), first Holy Communion and confirmation. In the youth ministry this aspect are digested and young people are assisted in their level of growing in faith (Wiafe, 59-60). We as a Church have to change our attitudes in this regards. The "serious challenge to the task that liturgy sets before us is the entertainment mentality that pervades our culture" (Singer-Towns, 2016). Hence the young people become like audience in the theatre. They just come for that and nothing else. Many of us are lucky enough we join the seminary, priestly and religious life and have receive much of advanced catechesis but for the other groups like the youth it's just the minimum. Catechesis is lacking. In fact, many parishes catechesis is still taught to the adult in the form of question and answer even in more than 100 years of Catholic faith there - eg, my home parish. In the parish yearly pastoral plan this is lacking. Catechesis is a life-long education. There is no stage we will say we have enough of it or have finished the course.

\section{Generation-gab between the Youth and other Adults}

In African Continent today, there is an unhealthy growing generation-gab between the youth and the adults (Martin, 2018). "Traditionally, the child in Africa had little or nothing to say about the running of tribal affairs. But, the on-going initiations were meant to groom the young person, so that he would take over from the elders with relative ease... The older generation, on its part, was supposed to see in youth, not rivals or useless and irresponsible children, but the future life-blood of the clan who had to be initiated into responsibility by following a well-organized programme" (Mbuy, 1996). Young people face the kind of "structural exclusion" even within the Church. It is also evident that this gap is felt much by the young people although "some parents, teachers, ministers, and counselors relate well with youth, others feel that the generation gap has become a canyon" (Rowatt, 2001). About $52 \%$ of youth, priests, religious and the laity affirm this gap. About $22 \%$ of all the groups say there is no such gap while $7 \%$ are not sure about the generation gap and 9\% say the gap is moderate. Jesus held these young people (Martin, 2018) as a model for us adult, "unless you turn and become like children, you will not enter the kingdom of heaven" (Mt 18: 3). What does it mean to have a share in God's kingdom? (Martin, 2018). Jesus points to us the young people. They are the model of discipleship by which the disciples were unable to carry; hence they stopped them coming to Jesus (Carroll, 2001). Some young people feel they are being asked by adult to accept adult agenda, precepts, cultural backdrop and their lens on the world. Schleiermacher argued that childhood and adulthood can be best understood not as successive phases of human development but as distinct spiritual perspectives that could coexist in any human being at the same time (Devries, 2001).

\section{Attitude of Pastors and How People view their Pastor}

There is much of "clerical status" and "adult status" kind of leadership (Martin, 2018) whereby the Church is only seen through the eyes of the clergy and adult which denies opportunity for the young to express their contribution. In verse 14 we see Jesus growing indignant. His emotion was "directed at the disciples' failure to understand Jesus and the nature of the kingdom that he preached" (Harrington, 2000). The disciples rebuked them. This attitude sounds like some of our pastors and our parents trying to forbid the young people from experiencing God's goodness and love. Though it is not said why the disciples wanted to prevent and considered children unimportant to Jesus their action shows a kind of an abuse of their authority (Lane, 359). Just like the disciples many of our pastors often feel they are uncomfortable with the young people. Many people look at priests as people who live in the Church and run the Church affairs. They are the ones who talks about God and being good. They preach and wed people. 


\section{"Let the Children Come to Me...For unto Them, the Kingdom of God Belongs" Mk 10:13-16: The Pastoral Challenges of this Invitation in African Church Today}

They baptized, visit the sick and bury the death. What about their own experience of their pastor? Others see them as cordial, one with positive attitude, one who organizes programmes, spend time with them and ready to offer even their last breath for their sake. Others say they have no time for them. They only mind their businesses; they have no time for the youth, can't manage the youth because they feel youth are nuisance and so fear to involve them (Martin, 2018). How the pastors relate to them may well affect how they view the Church and God throughout the rest of their lives. Many have these to say.

\section{Over-reaction and Fear: Trust and Confidentiality of Pastors}

We often are not prepared to invest the energy necessary in tending our sheep (the young people). We even most times over-react to them in their confused state, problem and moment of trials. There are many unasked questions to us. Father (Priest), when I was in those confusion, difficult moment, where were you? Were you there for me? Why then do you complain we are leaving the Church? (Rowatt, 2001). The young people are saying that we want to dismiss them from the church by over-reacting to them as a bleeding heart, but they find in us the same trait that makes us lean toward the left - compassion. We can demonstrate our concern for others when we stand up for our brothers and sisters whom we recognize have not been as gifted as we have been. They are saying we are privileged in many ways and because of this (Martin, 2018) we should have doors opened to them for direction and guidance - building confidence in them and not just fearing them or over-reacting. According to them it is not wrong to be granted such gifts and opportunities. It is a good (they say) because they need smart, compassionate people like us in positions of influence to help them grow in the Lord (Rosengren, 2002). When Jesus say "let the children come to me" (Mk 10:14) what does it mean to us today in Africa, America, Europe, Asia and etc? When Jesus took the young ones in his arms, touch them and bless them what does it mean today? Do we supposed Jesus was a hebephilia or pedophilia as in other part of the world where inviting a child or touching a child is against the law? It is a challenging time and even the devil tempted Jesus using the same scripture passages. We are afraid and have fear of engaging ourselves in the ministry to the youth (Martin, 2018) because of this kind of accusations. To have fear in the ministry God has call us to, is a failure in building the kingdom of God here on earth. We have lost the battle. Some of our pastors will say 'I am just not good at working with the youth'. Many people who say they are not good with young people are actually just afraid of trying. We have to be aware that we were once young. Quite often we turn away from the youth rather than guiding them (Mk 10: 29; Lk 14: 26). Jesus' radical stand gives us a criterion by which relating to the youth (Martin, 2018) must be evaluated. In fact, our churches out of their engagement with the biblical witness are called to vigorous, bold, and insistent advocacy for young people in our own time (Carroll, 2001).

We believe God is trustworthy. He is so faithful and we want our young people (Martin, 2018) to develop trust in God and in us. Young people of today learn to trust when we ourselves are trustworthy. One way they measure that fidelity to trust is by our presence and examples. They develop trust when they perceive that we the adult in their lives enjoy being around them and seem glad to have them around the Church. When Jesus invited them "let the children come to me (Mk 10:14) and blessed them and prayed with them, he certainly convey that he loves and trusts them (Lester, 1985). "Jesus does not advocate childishness nor does he have a naively romantizing attitude toward children" (Fuellenbach, 1995). Young people simply need someone who cares about what they are going through, and is willing to spend time and be honest with them. God created each of us with different gifts. Our gifts might best be used in parish ministry and parish ministry is not exclusive of youth ministry. As such what is our basic goal as pastor? Is it not to create a community of friends and trust? (Geaney, 1987). Youth ministers often form close relationships with young people and are sought out as adults who can help them with personal problems. Often young people discuss their feelings and actions with youth ministers and expect that they are kept confidential. Confidentiality is about trust and is associated with entrusting someone with a secret. Since the nature of the secret is that it is hidden, then confidentiality is about trusting someone not to reveal such information (Banks, 1999). I take a look back at why many people decline from the sacrament of confession this is one point many young people shared with me. They say that they do not have confidence of their priests because they no longer keep secret what belongs to that realm.

\section{Right Approach and Jesus' Invitation}

Few priests would intentionally inhibit young people from "coming to Jesus" just as the disciples did (Cf., Mk 10: 13-14). The question is whether we actively, purposefully, work to bring them into his presence. If we are not careful we will hide Jesus from them with rituals, symbols, and sermons too difficult for them to comprehend (Lester, 1985). The right approach is treating all young people as individuals with dignity and respect. It calls for listening carefully to their stories and take it seriously. It invites us to communicating all information and involving them in the process (Martin, 2018) of decision-making that may affect their lives (Banks, 1999). It calls for right attitude and approach just as Jesus did. We need to cultivate the right approach that will enable young people come closer to us and through our encounter they better see themselves as children of God and members of the Church (Martin, 2018). Jesus invited the young ones to spend time with him, to be around him and to talk with him. Can we envision their response to his smile, their careful answers to his gentle questions, their enjoyment of his company, their appreciation for his advocacy on their behalf? (Lester, 1985). Our Holy Father Benedict XVI urges priests to make youth a priority in their pastoral work. He said that young people must truly be the priority of our pastoral work, as they live in a world removed from God. The 
"Let the Children Come to Me...For unto Them, the Kingdom of God Belongs" Mk 10:13-16: The Pastoral Challenges of this Invitation in African Church Today

Pontiff added that young people are in great need of support to really be able to find their path to life (Zenith, "Vatican News," 2007). In our present time there are seductive voices everywhere and some are very erudite. These voices may claim numbers of young people on their side. What the leaders of the Church need to do today is not just be shaken by the storm that is raging all around them, but to hold on to what Christ has revealed. We are therefore call to re-examine our pastoral work where we failed and take seriously the youth ministry apostolate. We need pastors who follow Jesus' examples of open approach, welcoming attitude to young people and are ready to listen, dialogue and show understanding.

\section{Absence of Serious Youth Apostolate and Lack of Collaborative Ministry}

"The youth have not been fully integrated into the Church to see themselves as part of it" (Mbuy, 1996). As I travel across the country engaging myself in youth retreats and activities, and etc, I am blessed to talk with many clergy and laity about the Church's "need for youth ministry" (Martin, 2018). Here is what people say about the youth. Many people say the youth are ignorant. They assume to know. They are in a psychological mess and well as less committed in Church and small Christian community. Other look at them as rebellious while some say they need a lot of support. They are repulsive, uncontrolled and they spoil the customs and values. In other instances they are the most endangered group because they are the target. Others say they are aggressive while some say they are the future successors, liberators and hope of tomorrow (Mondo, 2006). All these may be true but are all the young people in our parishes in the same picture that cause the absence of serious youth apostolate? During conversations people always bring up the obstacles they face. Here are some common challenges people encounters along with some possible solutions that some areas have used to overcome them. In many of our parishes there is no youth apostolate. It is a fact. We often speak of obstacles, challenges or no personnel to do the youth work. We must not forget that the recipe for a youth program is actually very simple. First, we must identify the youth in our parish, and then find dedicated people who are grounded in the faith of the Church (Martin, 2018) and who are willing to spend time with them. These days we speak of collaborative ministry. We have to offer regular opportunities for the youth (Martin, 2018) to gather, to build spiritual friendships, and to serve others. In addition, we have to provide opportunities for them to discuss their faith and their daily lives with their peers and adults who care. The most part of it is that we must involve the youth in the process but at the same time not to fall into the trap of making them just another parish workforce.

\section{Fear and Sense of Inadequacy and Lack of Funds}

"Pastor's sense of inadequacy" (Lester, 1985) in ministry to the youth is high. Fear and sense of inadequacy may explain the absence of some pastors. For some it might be press of time, preparing sermons, meetings, teaching, planning weddings, raising budgets and funerals. These are good in themselves but I think it is lack of awareness that the youth in our parishes are part of that nation we have to evangelize. They also receive the invitation to the kingdom just as the adult do. Hence we have to rethink our pastoral ministry to the youth in our parishes. Youth ministry remains an answer where the parish priest remains the nucleus of all the activities of such ministry (Lester, 1985). It is not necessary he is there always but as long as working with the youth is in collaboration with other groups in the parish this kind of fear and inadequacy means nothing. Another area we can speak of no serious youth apostolate is often referred to the fact that our parishes have no enough funds for youth ministry. "During the AMECEA plenary of 1999 the Bishops stated: "Youth, we love you." And later in 2002 they stated: "We ask the AMECEA Pastoral Department to undertake a study on the need, possibility and convenience of establishing a desk for the Youth in the Department." "In realization to these good statements, what we see are fragmented individual initiatives that last as long as the individual last... There is the absence of a clear strategic focus on this group" (Mondo, 2006). We have to re-prioritize, show commitment, and include youth ministry (Martin, 2018) in the parish budget. We need to have the young people contribute something. There are many ways in which we can raise funds as long as we use it for the purpose. There are many faithful who can assist in whatever little way. We only have to approach them. I find parents are very willing to share in the growth of their children and to accompany their children to participate in activities or events that so clearly benefit them (cf., Mk 10:14) but we have to remember that young people are to be given access to Jesus (Lane, p. 360). Money should not be a hindrance to that or be an excuse to what we can do together with their parents.

The world of young people is a mission land for the Church to evangelize. We all know or have become aware of their problems which plague the environment in which the young people live: the collapse of values, doubts, crisis of faith, family breakdown, unemployment, consumerism, drugs, crime and eroticism. We have also seen that the rigidity of the Church rules forcefully applied by some pastors, cold liturgies and generation gab force many youth to become back benchers and passive participants of Church activities. Above all the attitudes of some pastors alienate them from active participation. But at the same time every young person has great thirst for God, even if at times this thirst is hidden behind an attitude of indifference or even hostility. This is evident in the number of young people who come to our Churches to find decisive meaning in their lives even those who are not yet baptize. The impression we give could scare these young people away. There is need for serious youth apostolate to keep the faith of the youth. As a Church we have to identify ourselves with the young. Jesus identifies himself with the young so that he can tell those who care for them that they have in effect cared for him (Jesus). Hence to receive the young ones is to care for, 
"Let the Children Come to Me...For unto Them, the Kingdom of God Belongs" Mk 10:13-16: The Pastoral Challenges of this Invitation in African Church Today

accept, and make room in our hearts, in our parish, in our Church for Jesus (Lester, 1985). It is true no one can better evangelize them than they themselves. They are the best evangelizers to their peers (Ecclesia in Africa, 93).

\section{Pastoral Care, Response, Presence among the Young and Spirituality of Youth Ministry}

The Church in Africa must take a decisive option for the youth who in their naivety are victims of the socio-political and economic malaise throughout the continent. They are caught at the crossroads, unable to understand, for most part, the wranglings among their elders and yet aware that these quarrels control their present and future lives. Africa is caught up in a web of rapidly changing socio-political economic situations in which our young people (Martin, 2018) are partly agents but largely victims (Mbuy, 1996). In the previous chapter we have spoken of the pastoral challenges of Jesus' invitation of the young ones, "let the children come to me, for to such the kingdom of God belongs" (Mk 10: 13-16). We exposed some of the challenges of our time and the possible way the Church can address and answer those challenges by instituting youth ministry in the Parishes as well as in the Dioceses. We are challenge because in most church establishments we lack pastoral care programmes for the youth. 'Let the children come' Jesus says he is present to be with them. Probably they must have asked same question the disciples asked, "Teacher, where are you staying? Come and see" (cf. Jn 1:38-39). This is a question many young people may ask us. "Come and see" challenges us to avail ourselves to journey with our young people. We have to share the word of God with them.

\section{Family Apostolate and Adapted Catechesis}

"Family problems invade most families on a regular basis. Strong families solve or contain them and go on with life as usual" (Rowatt, 2001). Archbishop Silvano Tomasi C.S., says that a "vital way to counteract the vulnerability of children is to strengthen the families in which they are meant to grow, to thrive and to be formed as responsible and productive citizens in their local communities and the wider society" (Benedict XVI, "Love: the Soul of the Church's Life and Action," No. 18). Being a parent in this day and age can be difficult when our values don't mirror those of society. There are times when it would just be much easier to 'give in.' Parents are under a lot of pressure, sometimes even from their own spouses. We parents need to stick to our guns and keep on reinforcing the values that we know are important in the long run in our children's lives. That is why it is important to become

aware of the confusion surrounding discussion of the family and convinced of its centrality to Church and society, several Christian groups have rallied to uphold and affirm the integrity of family life. One such group is the United States Catholic Conference of Bishops. It has issued a plan of Pastoral Action for family Ministry entitled A Vision and Strategy, in which they designated the 1980s as a decade of the family. They put forth four principles of preparation for this project: 1 . To raise awareness of the Church to the realities and problems facing families. 2. To seek ways for families to be caring. 3 . To instill in families a sense of mission. 4. To establish structures that enable and facilitate marriage and family ministry (Durka, 1988).

For many good Catholic parents their faith is evident in their children's actions and believes too. We share family joys and sufferings, praise and humiliations. Sharing and interaction brings people together. Nowadays parents don't seem to care whether or not their children are involved. The Church has to reach out to the family. Family apostolate is a concern today if not ever. The Church has every right and duty to see the family apostolate reclaim. We have to be aware also of the blocks to family apostolate. The clericalist model of some parishes is strongly in practice. The "Father" (Priest) knows best. We experience failure of pastoral vision and richness, a failure of the Church to transmit a sense of shared ministry and a failure to share the vision of the parish as a faith community (Chamberlain, 1988). Family ministry calls the parents to educate the children because it is seen as the central arena of education and growth (Durka, 1988). Therefore we need as a church to sensitize and even mobilize the society to support the family (Durka, 1988). We regard the Church as the family of God where we become brothers and sisters in Christ. The youth are included in this family through their baptism - sacrament of Christian initiation. If a family's concern is not for its new generation a (young person) then to whom is it for? Hence, the family of God (the Church) has the responsibility of monitoring the process of growing in faith of our youth and as the shepherd of this flock we must be aware of our role in accompanying these young people on their pilgrimage of life. We must be actively involved in the family. Nowadays this field is not so much to say it is the charism of this congregation or that. We can reach out to many through collaborative ministry where we all say, "it is our responsibility" and not "it is their responsibility" (Lester, 1985). In the heart and spirit of Vatican II parents are the primary educators of their children (Howard, A Parish Plan for Family Catechesis, 12). Therefore for the "family catechesis to work, it is important that all members of the family have a common topic that they can learn and discuss and absorb together" (Howard, 12). This can be done by identifying ones family and their needs, analyzing the current situation of the family and then gather together, explore and propose to the whole family becoming aware of the strategies of communication (Howard, 12). The family is not just a home where the Church gets many vocations to marriage, priestly and religious life. It is an environment of God's activity which must be supported by the parish and the Church as part of the Church's mission in extending God's rule into the world (Chamberlain, 1988). I will be a father to you, and you shall be my sons and daughters, says the Lord almighty (2 Cor 6: 18). 
"Let the Children Come to Me...For unto Them, the Kingdom of God Belongs" Mk 10:13-16: The Pastoral Challenges of this Invitation in African Church Today

In my interviews 35\% confirmed that this is taking place in their parishes. Another $25 \%$ says there simplified literature for the youth while $40 \%$ claim they are not sure and for them is something new. Adapted catechesis has to be taken in different stages of growth of our young people. The catechesis of elementary years, their needs and capacities must differ from those of $8^{\text {th }}$ to $11^{\text {th }}$ years of age as well as those from $12^{\text {th }}$ to $18^{\text {th }}$ years, the adolescent years and young adult years. The task then is to understand the needs to search for and maintain a strong sense of their own identity and to begin sharing their lives and visions, while responding to them through approaches which meet the criteria of the appropriate stage (Chamberlain, 1988). Youth catechesis must be revised and revitalized. Alienation from the Church or religious indifference is the backdrop of what the ministers must be aware. For sure this is as a result of lack of pastoral care in formation of our faithful. The most successful adapted catechesis is the one which addresses the problems affecting the lives of our young people (General Directory for Catechesis, 184). Adapted catechesis is another moment the church can be more pastorally presence among the young people. It is a concern we have to start implementing and not just saying it. The plenary of Bishops in 2002 stated: "We ask the AMECEA Pastoral Department to develop pastoral guidelines towards a catechesis adapted to the needs and expectations of the youth according to our resolution of AMECEA 1999 on the Youth, p. 2 No. 3:1" (Mondo, 2006) but in reality quite few priests are interested for adapted catechesis in their parishes. "Catechesis is not just history or theory. The challenge is now to take into the parish community a vision and ministry of catechesis built on the good practice seen over the centuries. It is a catechesis rooted in Scripture, Tradition, and Church teaching, and nourished by prayer" (Kelly, 2000). Catechesis is about people becoming catechist and teachers of catechesis.

\section{Human Relationships and Sexuality: Social life and Formation of Character}

In Africa cultural values and tradition are transmited through the process of socialization and traditional education. From the first day of birth, the African child is put in direct contact with the community, relatives and members of the community coming to see and celebrate. He or she begins the gradual process of socialization through which he or she begins to perceive the world around him or her. These are the facts which are modified in later stages of the child's growth in life (Mbaegbu, 2003). As the child grows he or she is confronted with many things in life. Social issues like poverty, violence, discrimination, contraception, abortion, divorce and suffering which catechesis can take up in youth group discussions as their character are being formed. Character, is an acquired quality where an individual acts authentically as a matter of habit in a wide variety of situations. Young people's character is in the making. Fr. Gerard shared with us that working with young people have helped him to adopt a certain different tone in how he pursue some things with the youth and other adult groups in his parish. Character formation will only occur on a context that is friendly to it (Whelan, 2006). In the past, family life was secure and very conducive for character formation of young people. People lived close together, contributing to the upbringing of the young people. As a Church, Parish or Diocese we have to come together in collaborative ministry in the formation of our young people (Martin, 2018). It is not only for parents alone nor the Parish Priest or the Religious Congregations working in the Parishes but a Youth ministry which is the responsibility of all (Mbaegbu, 2003). Through adapted catechesis we will better reach out in helping our youth. "In certain sense nothing can replaces family catechesis, especially for its positive and receptive environment... for its first explicit experience and practice of the faith" (General Directory for Catechesis, 178). The Christian community (parish, etc) has the responsibility to provide realistic aid by seeking dialogue with the families and by proposing appropriate forms of education and catechesis for the needs of their young (General Directory for Catechesis, 180).

For human relationships and sexuality, there are fears if we talk to the youth about them they will become more expose to get into pre-marital relationships, but by contrast, with youth groups we spend more time speaking about human relationships and sexuality. There is an urgent need in young people to address these issues and the minister must go in through this door if he or she expects a real engagement with the young people. Speaking of God's grace in this context of boy-girl relationships and human sexuality can have the greatest effect (Whelan, 2006). If we deny the fact what are the pictures we faced with today? What are the backdrops against which we are trying to hand on faith? There is need to adapt a catechesis suitable to the young people since they are on a journey of becoming aware of their identity and developing meaningful relationships with others. They may make a lot of mistakes, but if we accept these mistakes and do not blow them out of proportion, we will be in a better position to help them to grow. This does not mean that we are going to overlook every blunder, but that we intend to stand by them in their trails, especially when they go through crises of faith (Morissette, 1998). The declaration on Christian Education speaks of a kind of catechesis suitable to particular individuals and groups which are adapted to their ability, sex and national cultural traditions. As such catechetical instruction illumines and strengthens that faith. It develops a life in harmony with the spirit of Christ. It stimulates a conscious and fervent participation in the liturgical celebrations and encourages young people to take active part in the apostolate (Gravissimum Educationis, 1965).

\section{Faith Sharing and Catechesis in Schools}

Some families have their children in boarding schools from nursery even up to university level. For most of these young people their family is their friends. In many schools character formation and catechesis is no longer there. The sole purpose is academic excellence. Hence young people are only tune to academic performances than integral development of the young. Recently 


\section{"Let the Children Come to Me...For unto Them, the Kingdom of God Belongs" Mk 10:13-16: The Pastoral Challenges of this Invitation in African Church Today}

I visited one school in Tanzania. Catechesis (young adult formation program) is reflected in the school schedule. I took part in one of their sessions. They have three days of catechesis per week and each class fifty minutes. Young people coming home from such school on holidays expect to and should find similar ministry in their Parishes. "The clear message is one of faith into action. All catechesis is about translating faith into action, so that it impacts upon daily life. What is believed must make a difference to daily life" (Kelly, 2000). Here the understanding is that faith must be a lived and shared thing and not just a matter of referring to documents. Catechesis at the heart of it is the person of Jesus. It is not about personal opinions and options but the very teaching of Christ to his people. Therefore the more the Church whether at Parish, Diocese or Universal levels it has to give priority to catechesis. It is not enough to say one has done or gone for catechism before baptism, first communion, confirmation and little form of instruction before marriage. Many young people are confirmed and since that day they are not seen again in the Church. Why? (Kelly, 2000). The General Directory for Catechesis calls young people the 'first victims of the spiritual and cultural crisis gripping the world. It seems from the very moment of confirmation the process of Christian initiation is concluded and so for some they abandoned the practice of faith (General Directory for Catechesis, 181).

\section{Applied Faith (to Sports, Work, Study, and other Activities)}

Faith is the assent of our intellect to what God has revealed, not because we comprehend what God tells us in true, but only because we accept a truth on his authority that can neither deceive, nor be deceived. "Faith is an assent and a response. It necessarily comes after a proclamation, a challenge, an invitation. In other words, it is much more than an intellectual assent to some religious doctrine or a life style in conformity with some moral principles. Faith leads a person to enter into personal relationship with God through Jesus Christ" (Morissette, 1998). Therefore, the Church through its pastors has a big challenge to reevaluate the whole issue of catechesis. Sunday to Sunday masses is not good enough for catechesis. We need formative and educative programs to help our young people grow in faith at their own level. The Church is a "community where one is taught to love, and this education happens not despite but through the events of life" (Benedict XVI, "Love: the Soul of the Church's Life and Action," No. 18). A camping program, retreat, seminar, workshop, cultural festivals, sport meet are some of the events that any parish can plan and hold. These are the things that can attract more and more youth to our parishes. Young people love sports, work and study and social gatherings. Sport is a school of moral values. It is training in courage, in perseverance, in overcoming laziness and carelessness. They are of great interest for the formation of a personality. Our Holy Father says and I quote:

Your profession as athletes offers you, among other things, also the opportunity to improve your own personal spiritual state. Called as you are frequently engage in your competition..., you are in the best position to perceive the value of simple and immediate things, the call to goodness, ... and to meditate on the authentic values that are at the basis of human life. Discipline too, necessary for engaging in athletic performances, can be considered a prerequisite for spiritual elevation... and for a training of the spirit through the exercise of the virtues of prudence, justice, fortitude and temperance as well as the virtues of faith, hope and charity. Beloved young athletes, if you do all this you will be not excellent athletes but also good Christians and exemplary citizens who can witness to a certain lifestyle both in sporting arenas and in the environments, even more demanding, of your family and society (John Paul II, 1984).

We can apply faith to these events. Young people experience God in a very specific way different from the way we as adult would experience God. Therefore, the level of activity, scope and focus of youth ministry vary from place to place. At the national, diocesan and parish level we should have a clear picture of the young people who participate in youth activities. We cannot be sure how various services are targeted, what their real value is, how well our services and activities are known or whether they really meet young people's needs and make a change in their lives. Communities of faith have much to learn from young people's experience of God and their view of the world. We need a theology that values the perspectives of young people which address quite different questions from the ones that have dominated the Christian tradition (Devries, 2001).

Friedrich Schleiermacher (1768-1834) was struck by Jesus' identification with children. For him the difference between adult and children is that children play while the adult practice. What does he mean by this? For him play is an activity that is done for its own sake, for the present enjoyment of the activity, without regard to future outcomes. Practice, by contrast, is the arduous repetition and development of skills for the purpose of mastery and perfect execution of some future production. He further says that preoccupation with play might lead to irresponsibility, but preoccupation with practice can make a person rigid and closed off from fresh insight that arise as one actually experiences life in the moment (Devries, 2001). Such position challenges us to see youth activities as areas we can apply faith and help them to make a paradigm shift from play mentality to practice of virtues. "The major focus of parish as a community is people coming together to share events that mark their lives... the human experiences that touch life" (Geaney, 1987). Youth ministry plays an important role in creating such activities for youth and maintains spiritually and socially oriented needs of the youth. The Church however, has to open its doors in our parishes to the relationships and events on all levels of our daily life through which we have to experience God. Applied faith is centered in a place where the young people know that God is all and absolute good. They know that there is nothing to fear because there is a God who can listen and welcome them with open heart in all the events of life. They believe that all their needs and desires are met in God. For these reason there is 


\section{"Let the Children Come to Me...For unto Them, the Kingdom of God Belongs" Mk 10:13-16: The Pastoral Challenges of this Invitation in African Church Today}

a great need for sound and active youth ministry in our Parishes and at diocesan level. Though youth ministry is more challen ging today but we cannot shy off by saying it is too demanding. We have to open up the doors and let them come in. Jesus is telling us to listen to their experiences as he did. "Faith must penetrate all aspects of the human condition, including it physical aspects. The more human our spirit becomes the more it will identify itself with our body; and divine grace, to be truly human" (Ryan, 1986).

\section{Images of Youth Ministry/Apostolate from the Scripture}

Some years ago youth ministry was for Catholics something of protestant tones. We spoke much of Catholic Youth Organization (C.Y.O.) but today it has change. There is a closer coordination of various ministries in our pastoral actions. It is true that most young people have serious misgivings about retreats, youth groups, and gatherings. At almost every event I lead, there are at least one or two participants who are there only because their parents made them go. However, when they experience the bond that comes from being with other people of their age, talking about things that concern them, and having a good time, they almost always want to know when the next event is. Attentiveness to the needs of the young people does not mean neglect of the needs and gifts of the adult in the Church. Here is what people say about youth ministry. About $73 \%$ of the youth say there is a great need for youth ministry in their respective parishes while $25 \%$ say the youth apostolate in their parishes need a shepherd who is constant and consistent ministering to his flock. Other youth about $11 \%$ say there is no need since some parish council does not care so they are comfortable the way the situation is. About $68 \%$ of priest, religious and the laity say there is need for youth ministry but some of them express the fact that they have no time for full time ministry to the youth, lack of funds and personnel in this area while $24 \%$ of the adult say it will be a divided attention in the parish. And $8 \%$ adult say there is no need.

There is a difference between a theology of youth ministry and a theology of young people. When groups of young people begin to speak of their encounter with God, and then a theology which is indigenous to them begins to emerge. A theology of youth ministry, on the other hand, seeks to demonstrate how our understanding of God shapes and influences the practice of youth ministry. Youth ministry is the mission of God (Missio Dei) not ours which aims at announcing the good news of salvation to all especially to the young people, providing answers to the big questions of life of young people. We work among the young people because we believe in God who invited all to his kingdom. Youth ministry is grounded in the missionary nature of God. We are only call to participate, to share in seeking God (Ward, 1983).

In the Scripture we find young people at the very center (Is 49: 14-16a, Mt 18: 1-5). Jesus in the gospel put children and young people at the centre. They are models of trust and simplicity. Youth ministry therefore places young people at the centre. In the Exodus experience we see God who walks and stands by side of his people (Ex 13: 17, 20-22). In the gospel of Luke we see the same God who journey with his people (Lk 24: 13-35). He interacts and explains to the two disciples everything about the Scripture. $\mathrm{He}$ is the Emmanuel - God with us. This is an invitation to meet the young people wherever they are and take initiative to listens to their stories and guides them. David in the Old Testament is depicted as stronger because God was with him. He was full of youthful energy and God's abiding (1 Sam 17: 40-51). From his youthfulness God did great thing for the Israelites just like the "small boy" in John's gospel story. From just that boy Jesus made the miracle of feeding the 5,000 people (Jn 6: 3-15). We have to spot the gift of our young people. Prophet Elisha restores life to the child of his hostess ( $2 \mathrm{Kg} 4: 8,15-21,32-37$ ). Jesus gave life (life to the full) back to Jairus daughter, Talita Kum! (Mk 5: 22-24, 35-43). Youth ministry is a life-giving ministry. We are called to be defender of life and promotion of the whole being of the young. Jesus is the true educator (Jer 18: 1-6; Lk 13: 6-9). We see the image of a potter and the clay and the patient of the gardener with the barren fig tree. The potter patiently takes time to mold with all carefulness. These beautiful examples challenge us to exercise patient with our young people. Our young people do have their crosses (Num 21: 4-9; Phil 2: 6-11; Jn 3: 13-17). Therefore we need to be close to them in times of difficulties, problems and crisis (Mondo, 2006). Youth ministry is that aspect of the ministry of the word directed to the youth, for the youth, with the youth and sometimes by the youth. It is any form of activity by the Church which aims at the spiritual formation of the young people. It refers to all activities where young people are at the center for their integral growth and development. Whenever young people come together for any activity it is giving them the human formation and equipping them to face life as young people and to live a focus life (Mbaegbu, 2003) thereby becoming "good Christians and honest citizens" (St. John Bosco, 1815-1888).

\section{Responsible and Active Participation}

We all say the youth of these days are different. Did they choose to be so for the sake of fun or we the adult have somehow contributed to them being so by ignoring to look critically at the signs of time? (Mbaegbu, 2003). Youth ministry brings about responsible and active youth. However, it is a challenge to coordinate different sectors in the parish and at the same time to keep the youth apostolate in mind. There are few who are able to integrate all ministries. Youth ministry or youth apostolate seeks to draw young people to responsible participation in the life, mission and work of the faith community. It works to foster the total personal and spiritual growth of each young person. The critical approach we often seen and received from the young people is not really a rebellion against authority or discipline. It is a search for reason and justification. They want and cry for justice. This is what we have termed as tug of war between youth and parents or pastors and leaders. Youth ministry calls the young people to participate in activities that will assist them in their faith formation and growth. Our young people are not interested in adult stuff. 


\section{"Let the Children Come to Me...For unto Them, the Kingdom of God Belongs" Mk 10:13-16: The Pastoral Challenges of this Invitation in African Church Today}

They feel to make their faith journey among their peers. We need to remember what we as the Church have to offer. In a world of increasing violence, indifference and despair, only the Church can tell the young people that they are so loved. Only the Church can offer a place that young people can go to be truly themselves and be able to honestly share their concerns and fears with others and adults. It is only in the Church where young people can experience and learn about the real life in Christ.

\section{Having the Youth at Heart and Tips for Pastoral Presence among the Youth}

Fr. Gerard in a symposium 2004 said that youth ministry is best understood and can be best explained within the context of Christian ministry in the Church. He spoke of Cardinal Martini, Archbishop of Milan who has the youth in his heart, organizing and holding prayers for youth and thousands of young people attended the service every Friday evenings instead of disco. The media once was much interested and asked the Archbishop for press conference about the opinion of the youth. He spoke of joy of love, despair of rejection, feelings of hurt, desire for revenge, repentance and he added that the thoughts and feelings of the youth are just like the thoughts and feelings of the authors of the Psalms, of praise, of thanksgiving, of war, of lament, of appeal for forgiveness (Whelan, 2006). Do we have the young people at heart to be parishioners or belong to our parish? They are and have right to be recipient of our pastoral care. We have the responsibility by taking seriously the youth ministry which answers the pastoral needs of our young people. A good shepherd looks for the lost sheep irrespective of the age. Was there any age limit on the sheep who were cared for by the shepherd? The youngest lamp was equally subject of the shepherd guidance and provision of necessary needs. Therefore as parishioners our youth need our presence and guidance (Lester, 1985). Let the children come to me (Mk 10: 14) Jesus did not ask for favour so we don't need to give pastoral attention to the youth because we will receive favours. In fact winning their heart is an important pastoral task. Therefore, we have to relate to them creatively in nurturing their spiritual development and meeting their needs not our needs (Andrew D. Lester, 1985). Unless youth ministry is able to say, stand up and walk to all the cripple youth sitting at the entrance of our sophisticated cathedrals, parishes and religious communities we are simply downplaying our pastoral care (Mbaegbu, 2003). The Holy Father draws to the attention of youth counselors, ministers and guides to respect the desire of the young to their own persons and to find love. However, these young people need guides and they want them to be close at hand. When the young turn to us (authority figures), they do so because they see in us a wealth of human warmth and a willingness to walk with them along the paths they are following (Avallone, 1999). Pastoral presence among the youth requires that we have to be there, wherever the young people are. Our presence matters more than we may realize. The young people want to see us in their midst. We need to take first initiative to meet them, greet them, at least smile and talk to them of things they are interested in. We should be familiar, and not aloof to them. We should not imitate them in language, dress code or behaviour. We should identify ourselves with the young but not to become identical with them. We have to be reasonable. It is important to consult the young and correct them but never humiliate them. There is a greater call to be honest. We should not be cruel but ever ready to help them to reflect. We have to praise and affirm them when they do something well however small it may be or appear. We have to learn to be impartial and be prepared for unexpected challenges and problems. Above all we need to identify their capability, encourage them and demand. We should help them discover their gifts and talents and demand that they give of their best to others. We should make them responsible for their formation. As they grow, more and more initiative and decision making should be left to them. We should give them chances to serve. They are energetic, generous and idealistic. They need chances to help, to serve, to sacrifice themselves for a cause (Fr. Glen, Seminar Notes, 2007).

\section{Keys to the Hearts of Young People Reason, Religion and Loving Kindness}

Reason is the "ability to know and understand the human dynamics of the young and to be able to communicate and dialogue with them which calls for an active and constant presence on the part of the educator or minister. Through a friendly presence, the young people come to know that the minister is available as a friend, guide and counselor (Avallone, 1999). Reason safeguards a relationship based on love from degenerating into mere sentimentality. It supplies the necessary balance in an atmosphere of understanding, acceptance and respect that allows the youth minister to function. Reason calls for making the rules few in order to safeguard spontaneity. Formulating such rules must be simple and clear and sometimes need that the young people (Ekanem, 2009). formulate their own rules. This way they take responsibility of abiding. These rules must have functional values and not just an end in themselves. Above all they must not be made for the convenience of the minister. "It is easy to understand the attraction of 'religious experience,' especially in a secularized world which has lost confidence in traditional religious institutions. People need not just to belong, but to feel that they belong, that belonging makes an observable difference" (Barnes, 1998). Religion plays a very vital role in the lives of the young people. In the youth centres and ministries the young people seems and feels out of place when our presence becomes so much of result oriented that all our emphasis is in the outward maturity rather than inward growth. Religion is about walking with the young to Jesus. It is about a journey of faith with the young people which call to holiness (Avallone, 1999). 

of this Invitation in African Church Today

"It is not sufficient to love young people; they must know they are loved" (St. John Bosco, 1815-1888). Learning and acceptance begins in a relationship of love, trust and confidence. The young people listens and learn from those they love and in an atmosphere of trust and confident. These goes contrary to fear and dishonesty. It is only where there is love that there is true growth hence, Don Bosco said, "love what the young people love that they may in turn love what you love." Loving kindness creates a persuasive atmosphere where self-expression is fostered and openness encouraged. This kind of interpersonal relationship brings forth confidence between the young people and the ministers. Through kindness the parties are able to effect the negative impression of "generation-gap" and foster a balance by blending freedom with responsibility, by bringing together the old and the new. In fact, this promotes humanism. This element finds true expression in a family spirit which exists in the Church and families as spirit of joy, love and peace (Avallone, 1999). This loving of what they love implies listening to them even when at times requires taking our whole time. The second point is availability. Being available to the young people is very important. They value our time with them when they need us much more than what we may say. The third one is being creative. Our presence with the young people (Ekanem, 2009) need be creative so that what we love will in turn be what they love.

\section{Committed Example and Interest in what Interests the Youth}

In one occasion John Paul II was asked whether or not he was so optimistic about the youth of today. It is rather gloomy with regard to youth social situation. The social forces: family breakdown, decline of trust in public and church officials due to corruption and questionable practices, the impact of mass media in regard to violence, crime and sexual freedom and many others are the areas that influences life and behaviour of the youth. The Pope says that our young people suffer so much of a malaise because of low self-esteem, insecurity about the future and loneliness all stemming from a sense of abandonment (Avallone, 1999). When we read from the gospel it is interesting to note the marginalized and religious outcasts in quite a large number. These are the people who draw much closer to Jesus for the purpose of listening to Jesus. In the same time the religious elite, the Pharisees and the Scribes keep their distance to avoid contamination. They rejected and shunned any fellowship with sinners. In fact Jesus is accused of welcoming and entertaining and eating with people of such reputation (Winstanley, Don Bosco's Gospel Way, 14). Our parishes should become for our young people a school, a church, a playground and a home (Winstanley, Don Bosco's Gospel Way, 14). In April 25, 1884 Don Bosco was asked by a reporter of a French Newspaper on how he was able to be and educate the young people. In his reply, he said; let the young people have full liberty to do the things that are pleasing to them. For him the secret is to discover their potentials and abilities and then seek to develop them. Each young person does with pleasure only what he knows he can accomplish (Don Bosco, Biographical Memoirs, Vol. 17, p. 85-86). The Pope "finds in the young an immense potential for good and for creative possibility" (Avallone, 1999). The true educator who shares the life of the young, is interested in their problems, tries to become aware of how they see things. He takes part in their sport and cultural activities and in their conversations. As a mature and responsible friend he maps out ways and meaning of doing good and ready to intervene in problem solving. In this kind of atmosphere he is not looked upon as a "superior," but as a father, brother and friend (Avallone, 1999).

\section{Understanding Presence and Growing in the Family Spirit}

"Is there really hope in the young? Pope John Paul II on $22^{\text {nd }}$ October 1978 at the inauguration of his papal ministry said this to the young people, "You are the hope of the Church and of the world. You are my hope." Previously we have spoken about pastoral presence among the young people. Here we want to talk about the kind of presence the help much in our pastoral work with the young people. Presence means being with the young in a way that is friendly, understanding, attentive, lively, caring and creative. This effective presence is evident in the understanding of the three pillars of being with the young and that is, reason, religion and loving kindness. "The secret is presence, to spend time with youth, to be actively present among them. To enter their world of games and sports and music is the key to an understanding of their values and an ability to lead them to greater, higher, values; and eventually, spiritual ones. As Don Bosco would say, we love the things they love and then bring them to love the things we love" (Avallone, 1999). It must be an endearing presence that motivates, infuses enthusiasm, encourages and optimistic. Imposition of things on the young people has proved counterproductive. Our presence must allow them to thirst for knowledge. Our presence should be that which the young people feel known, loved and accepted. Our presence must be incarnational and based on sound moral values. And should be creative and open to discovery. We need a presence that is corrective and not punitive.

\section{Dialogue and Signs and Bearers of God's Love}

"The young people are agitating, not just for new ways of doing things, but for a new way of being Church" (Mbuy, 1996). This drive of being a new Church always bring about misunderstanding, conflict that resulted to banning of youth groups in some parishes even to an extend of saying they (youth) should not enter the Church premises. This has happened. It is not a formulation. Teachers, parents, religious and priests complain so much about young people saying that they lack character, commitment, and ambition. They cheat, lie, avoid responsibility and have no respect. Many occasions we have wasted time and energy to complain rather than reflect why these young people behave in this way. Probably we may be able to find reasons and be able to help them better. In fact, the more we bureaucratically react to them the more we help them not (Rowatt, 2001). I took my interviews from the 


\section{"Let the Children Come to Me...For unto Them, the Kingdom of God Belongs" Mk 10:13-16: The Pastoral Challenges of this Invitation in African Church Today}

people. About $70 \%$ of the youth say that rarely they have dialogue whenever they have some problems with their church. $25 \%$ of youth say they only dialogue during yearly youth rally where some of their questions are answered while about $5 \%$ they do not have at all. I took the same point to the elders (priests, religious and laity) they say it is very difficult to dialogue with the youth before you say one word they have spoken five they are not ready to change or amend their position. The plenary meeting of the Amecea Bishops in 2002 stated: "We ask the AMECEA Pastoral Department to keep permanent contact and dialogue, through the National Secretaries, concerning the Youth Associations, Movement and special activities" (Mondo, 2006). Dialogue is one of the keys to the heart of the young people. They want to share and take part in problem solving and decision-making in any thing that concerns them. Dialogue brings about reciprocal communication leading to a common goal or interpersonal communion. It envisions an attitude of respect and friendships. As a matter of fact we can achieve a lot if we are able to dialogue with our young people. Young people need dialogue, respect and challenge in order to grow. Dialogue cannot be dissociated from the need for truth, freedom and justice. Dialogue of this nature brings about understanding, appreciation of one's gift and deepening of one's faith. It provides young people with regular opportunities to get together and discuss common concerns.

Young people enjoy being loved hence we (parishes) which is a home, a parish, a playground and a school have to become signs and bearers of God's love to them. Our world has known many prophets of hope and optimism for the young people. One of such is St. John Bosco whom Pope John Paul II in 1988 proclaimed the "Father and Teacher of Youth" (Christifideles Laici, 1988, 8). We have to become signs and bearers of God's love for the young. St. John Bosco gave us an example in these memorable words: "That you are young is enough to make me love very much," "I have promise God that I would give of myself to my last breath for my boys." These are prophetic words whose influence continues today in the Church as a kind of pastoral charity towards the young which is characterized by a sense of family and joy which brings about in the young good Christians and honest citizens (Avallone, 1999). The Church today must show forth that truly he is the sign and bearers of God's love. Once the young realize this, their growth and sense of belonging to God's family deepens.

\section{Fostering a Holistic Youth Spirituality}

Is our spiritual hunger fed by our parish life and worship today? Many people do not find their spiritual hunger satisfied by what they experience in their parishes each week hence many look forward to such in other places. It seems that there is a dichotomy between spirituality and religion. In my ministry and in my friendships I am confronted with persons who sincerely believe that they are unspiritual when in fact they are deeply spiritual persons. It is because they have not found a spirituality which enables them to integrate their drive for life, celebration and sexuality into a commitment which includes Christian sexual morality, prayer and involvement with a Eucharistic community and so they are force into a false dilemma. They feel they have to choose between a Christian commitment and a life partially away from the Church, sacraments, prayer and morality (Ryan, 1986). Therefore the Church in Africa is call to foster a holistic spirituality that is youthful. Youth spirituality sustains the youth ministry and youth groups in our parishes. Youth spirituality is unique and very youthful.

"The term spirituality refers to both a lived experience and an academic discipline. For Christians, it means one's entire life as understood, felt, imagined, and decided upon in relationship to God, in Christ Jesus, empowered by the Spirit" (Conn, 1989). Gordon S. Wakefield defines spirituality as a "word which has come much into vogue to describe those attitudes, beliefs, practices which animate people's lives and help them to reach out towards super-sensible realities" (Wakefield, 1997). Christian Spirituality concerns and embraces the whole life (Wakefield, 1997). By spirituality we mean the lived, personal dimensions of faith, where the call to prayer and service is existential: something whole and pressing. Saint Paul understood spirituality as life in Christ. For him the experience of day to day life in Christ centres on bearing one another's burdens. He testifies through his experience of the Risen Lord and his later struggles and failure in ministry. The early Christianity understood spirituality as union with God and love of neighbour. Through baptism and nourishment they share in the Lord's Supper and a common faith was experienced while the medieval time interprets its experience of being human in the image and likeness of God. They envisioned a wholehearted conformity to Christ's love and care for all. The reformers picked it as a total surrender to God's free love in Christ and fidelity to one's interior calling. For the modern times they continued to respond to ideas and events which open new perspectives on faith and reason, mission, science, social structures and world religions. However the Vatican II gives us a holistic spirituality which adheres to God at the centre of everything and seeks to cooperate with God in bringing the kingdom of God to every sphere of life (Conn, 1989). It is living each day immersed in the mystery of God and choosing to allow such mysterious and all-pervading presence of a living God to give meaning and purpose to one's life. It lies in realizing our true destiny which is a gift from God. It consists in recollecting ourselves within to allow ourselves be loved by God.

\section{Youth Spirituality: Spirituality of Celebrating Life in Joy and Optimism}

Youth Spirituality is the art of listening to God revealing himself in life and of responding to God's call according to our gifts. As such it requires an attitude with a capacity to integrate faith and life, build on strong foundations, to dialogue and reconcile with differences, reading the signs of times with faith, sense of Joy (yes to life), solidarity with the weak and most needy and a 


\section{"Let the Children Come to Me...For unto Them, the Kingdom of God Belongs" Mk 10:13-16: The Pastoral Challenges of this Invitation in African Church Today}

mature sense of community. Youth Spirituality therefore may be understood as concerned with practice rather than theory, life rather than law, embodied faith rather than intellectual believe, and experience rather than academic knowledge. It is a spirituality that is sensitive to context as they vary from place to place. "Lord, to whom shall we go? You have the words of eternal life." It is in the difficult moments, in moments of trial, that the quality of decisions is measured. Thus it is in this difficult time that each one of us will be called to have the courage of our decision. "Whoever clings to me I will deliver; whoever knows my name I will set on high. All who call upon me I will answer. I will be with them in distress; I will deliver them and give them honor. With length of days I will satisfy them and show them my saving power" (Ps 91: 14-16). Educating youth in a secular world we have to develop some characteristics in them which include joy, gratitude, perseverance, responsibility, and patience. These are all steadfastly found in Scripture. It is no coincidence that these traits will ultimately help our children become successful, moral, and compassionate adults. Young people live life as a feast. Music, drama, theatre, dance, games, sports and picnics become their way of celebrating life. We spoke about applied faith in the previous chapter. This is where faith in God can be expressed through these festivity, gratitude and praise, joy and optimism (Avallone, 1999). Holiness consists in being happy (St. John Bosco 1815-1888). We have to live our life, our faith as a feast. Young people love music, theatre, outings, sports, and joyful daily experience. All these bring them joy and make them optimistic. St. John Bosco pointed to the young people a simple, serene and happy form of holiness. Dear young people, I have asked you to be "prophets of life and love." I also ask you to be "prophets of joy:" the world must recognize us by our ability to communicate to our peers the sign of a great hope which has already been fulfilled: Jesus, who for our sake died and rose again (John Paul II, 1996).

\section{Spirituality of Fulfilling Daily Tasks of Life Faithfully and Accepting Daily Cross}

There is more to life than just fun and feasts. Sometimes young people feel fulfilling their daily task is a bitter truth for them to accept. Helping them to see the importance and relevance of work they can do and perform wonders bringing all what is in their heart full of joy and gratitude. In fact holiness equally consists in happily fulfilling one's duty. Such spirituality is for everyone. It is not a style of living that leave behind the daily life. It is about living each day in the mystery of God. In the spirituality of daily life the challenge today to any believer is to transform life experience into the experience of God. It is by opening up to the reality of life and integrates it that the young people can harmoniously live an authentic life. "We cannot speak about the cross without considering God's love for us, the fact that God wishes to shower us with good things. With his invitation "follow me," Jesus not only says again to his disciples: take me as your model, but also: share my life and my choices, and stake your life for love of God and for neighbour together with me" (John Paul II, 2000). The daily tasks of life come with crosses we have to carry and follow Christ. This is about living our problems, trials, difficulties, hardships and pains positively.

\section{Spirituality of Living Life as a Vocation and Mission}

Spirituality of ordinary life and living life as a vocation and mission is a journey that is fraught with many questions, failures and victories. It is a journey within (from self-discovery through self-acceptance to self-expression) and without (from critical reflection on social issues through discernment of one's vocation to creating a better world). This is the time many young people ask series of questions starting from the self. To fuse all these in the young people is an area that calls for commitment. The spirituality of living life as a vocation and mission is a call to friendship with Jesus (Avallone, 1999). Jesus' invitation "come and see," (cf., Jn 1: 38-39) the young people meet Jesus where men and women are suffering and hoping in the little villages, scattered across the continents and seemingly on the fringe of history, as Nazareth was when God sent his Angel to Mary; in the huge metropolises, where millions of human beings live often as strangers. In reality, every human being is a "fellow citizen" of Christ John Paul II, 1997). It is a spirituality that recognizes the value and dignity of life, that all are called to go for mission. The world of the young people is a mission land. They feel challenge to be missionary of their own peers but at the same time happy to be missionary in many little ways in our parishes.

\section{Spirituality of Responsible Service and Socio-political Involvement}

Spirituality of responsible service (Paul P. Avallone, 1999) is a ministry of diakonia (service) which can take many forms, but all of its manifestations share a concern for attending to the needs of others. What is distinctive about Christian diakonia (service) is that service to others is not undertaken merely for the sake of the other, but because of the conversion it effects in the one who serves (Gaillardetz, 32). Young people are expected to be witnesses of the One whom they have met and who gives them life. In daily lives they have to be intrepid witnesses of a love that is stronger than death. The Holy Father challenges the youth to put their talents and youthful enthusiasm at the service of the proclamation of the Good News. He encourages them to be enthusiastic friends of Jesus who present the Lord to all those who wish to see him, especially those who are farthest away from him. God uses human friendship to lead hearts to the source of divine charity. He said; feel responsible for the evangelisation of your friends and all your contemporaries" (John Paul II, 2004). Young people love giving services. It's enough to give them that responsibility. Youth ministry prepares them to that and I would like to encourage them with words of the Holy Father, 

of this Invitation in African Church Today

Yes, now is the time for mission! In your Dioceses and parishes, in your movements, associations and communities, Christ is calling you. The Church welcomes you and wishes to be your home and your school of communion and prayer. Study the Word of God and let it enlighten your minds and hearts. Draw strength from the sacramental grace of Reconciliation and the Eucharist. Visit the Lord in that "heart to heart" contact that is Eucharistic Adoration. Day after day, you will receive new energy to help you to bring comfort to the suffering and peace to the world. Many people are wounded by life: they are excluded from economic progress, and are without a home, a family, a job; there are people who are lost in a world of false illusions, or have abandoned all hope. By contemplating the light radiant on the face of the Risen Christ, you will learn to live as "children of the light and children of the day" (1 Th 5:5), and in this way you will show that "the fruit of light is found in all that is good and right and true Eph 5:9 (John Paul II, 2002).

Jesus dwells in our parishes, in the communities in which we live, in the associations and ecclesial movements to which we belong, as well as in many contemporary forms of grouping and apostolate at the service of the new evangelization. This rich variety of charisms is a benefit for the whole Church, and an encouragement for every believer to place his or her capacities at the service of the one Lord, fount of salvation for all humankind (John Paul II, 1997).

\section{Spirituality of Communion in the Church}

Friend, Teacher and Saviour are the titles that can best describe the person of Jesus to the young in the spiritual experience. Living the spirit is to help youth to form bonds of close friendship with Jesus. Communion is that which seeks the building up of the kingdom of God on earth. Young people as friends share and celebrate together the joy of living in communion. Through this communion they help each other. The experience of a youth ministry can bring about a tremendous and better understanding and appreciation of the communion in the Church. The Parish community then can create such environment where young people feel they are in communion (Avallone, 1999).

\section{CONCLUSION}

In Warsaw, Poland, the 4th World Congress of Families where participants came from as far away as Chile, Mexico, New Zealand, Australia, Afghanistan, Nepal, Nigeria, South Africa, Kenya, DRC and the Philippines. It highlights a key social concern when it talks of the fallout of weak family life. They say, family is life, and without it there is no state or government. The congress discussed and analyzed issues impacting the family such as abortion, the move to legitimize so-called same-sex marriage, population decline, pornography, and family attacks in news, entertainment and social media. Margarita Zabala Gómez del Campo, the first lady of Mexico said, "today, more than ever before throughout the world, there is a need to think of the family, because when you protect the family, you are protecting society and the nation" (4 ${ }^{\text {th }}$ World Congress of Families, 2007). Cardinal Alfonso López Trujillo, president of the Pontifical Council for the Family, at the closing session, comments "The vocation of marriage is written in the very nature of man and woman." He recalled the importance of recognizing the falsehood of relativism that affect Christendom. As a Church we don't need to sit back and watch. We have to help the family redeem her role and place through organized programmes and seminars at parish levels to equip, empower and catechize our Christian families.

We have to adapt a catechesis suitable for the youth. We have to celebrate the Eucharist together. Pope John Paul II challenges the youth that in their groups they should multiply the occasions for hearing and studying the word of the Lord, especially through the lectio divina which they are going to discover the secrets of the heart of God and will derive profit for discerning situations and transforming reality. Guided by Holy Scripture, they will be able to recognize the Lord's presence in their daily life. Christ is present in the scripture, the Eucharist and the church. The Church's presence with the young people through her pastors is seriously required. The persona Christi must be felt and the young people be given the opportunity to experience and express their love for Christ (John Paul II, 1997).

If the emphasis in theology today is validly placed on the vertical moving downward to the depths of the human; if we really believe that in depthing the feelings of normal everyday human existence - feelings of hurt, of joy, of confusion, of peace, of insecurity, of empathy and so on - there is a spiritual experience, then certain forms of activity in which we have powerful and enthralling experiences have value and relevancy for our spiritual life and growth (Ryan, 1986).

"The most necessary task of the Christian minister is to facilitate a graced encounter between an individual and Jesus Christ" (Whelan, 2006). Youth ministry calls us to serve a broad range of youth. It is therefore, the role of the Christian community to show to young people that they are a community of care. Youth ministry serves the total person therefore, the beloved community welcomes young people into the enriching communal existence. It is the community's responsibility which is characterized by gentleness and friendship to welcome the young people. This is exactly Jesus' approach when he said; let the children come to me. Therefore the youth minister should note that youth ministry takes into consideration the total situation of young people. It is a ministry of friendship which functions out of an affirmation of gifts in the community - common unity and the youth to minister under the motto: "Youth Serving Youth." To be true youth minister we must carry within the essential dynamics of proclaiming the Good News in ways which the young people would understand (Ward, 1983). 

of this Invitation in African Church Today

The Catholic Church must come to terms with the challenge of ministering to its youth population, or else it may risk losing a significant portion of the faithful for generations to come. With pastoral presence we have to remove all the prejudices and fears which seems to be at the root of our uneasiness to be with the young people. Actually we fear what we do not understand. Pastoral care and presence requires an implementation of the Church as a family of God where young people are part. Youth ministry should be in every parish where youth groups are formed (Rosengren, 2002).

Finally youth spirituality is the unfolding and articulation of the divine dimension in experience. We sometimes look on spirituality as something reserved for people of religious affiliations. It is simply one dimension of our being human persons. It is something we share. It is our ability to see beneath the surface of life, to discern deeper meaning under the veneer of everyday experience. Every parish is responsible to prepare his people, provide necessary equipment needed for catechesis. At the same time in reading the 'signs of times' the Church must interpret its teachings for the world of today and not to water down or compromise them in a way palatable to a world whose values may be different but for the sake of building the kingdom of God on earth (Kelly, 2000).

\section{REFERENCES}

1) Ambrozic, Aloysius M. The Hidden Kingdom, A Redaction - Critical Study of the References to the Kingdom of God in Mark's Gospel, Washington DC: The Catholic Biblical Association of America, 1972.

2) Avallone, Paul P. Keys to the Hearts of Youth, New Rochelle: Salesiana Publishers, 1999.

3) Banks, Sarah. (ed.), Ethical Issues in Youth Work, New York: Routledge, 1999.

4) Barnes, Michael. "The Public, the Private and the Personal Dimensions of Religious Experience," London: The Way Publications, 1998.

5) Benedict XVI, "Love: the Soul of the Church's Life and Action,” L'osservatore Romano, No.18, May 2, 2007.

6) Carroll, John. T. "Children in the Bible" Interpretation: A Journal of Bible and Theology, Vol. 55, No. 2 , April 2001.

7) Chamberlain, Garry L. Fostering Faith A Minister's Guide to Faith Development, Mahwah: Paulist Press, 1988.

8) Code of the Canon Law, 1983.

9) Congregation for the Clergy, "General Directory for Catechesis," London: Catholic Truth Society, 2002.

10) Conn, Joann Wolski. Spirituality and Personal Maturity, New York: Paulist Press, 1989.

11) Devries, Dawn. “Toward a Theology of Childhood," Interpretation: A Journal of Bible and Theology, Vol. 55, No. 2, April 2001.

12) Don Bosco, Biographical Memoirs, Vol. 17, p. 85-86.

13) Durka, Gloria. "The Changing Family: Perspectives for Family Ministry," Religious Education, Vol. 83, No. 4, Fall, 1988.

14) Ekanem, James. "Encountering God in the Sacrament of Reconciliation: A Liturgical Catechesis for the Young People," 2009.

15) Fallon, Michael. The Gospel according to Saint Mark An Introductory Commentary, Australia: Chevalier Press, 1995.

16) Fuellenbach, John. The Kingdom of God the Message of Jesus Today, New York: Orbis Books, 1995.

17) Geaney, Dennis J. Quest for Community Tomorrow's Parish Today, Notre Dame, Indiana: Ave Maris Press, 1987.

18) Hargreaves, John. A Guide to St Mark’s Gospel, London: SPCK, 1979.

19) Harrington, Daniel J. "The Gospel According to Mark," The New Jerusalem Biblical Commentary, Student Edition, No. 63, 2000.

20) Howard, Karen L. A Parish Plan for Family Catechesis, p. 12.

21) John Paul II, Apostolic Exhortation "Christifideles Laici," on the Vocation and Mission of the Lay Faithful in the Church and in the World, Rome, 30 December, 1988, No. 8.

22) - Apostolic Exhortation "Ecclesia in Africa," on the Church in Africa, Nairobi: Paulines Publications Africa, 1995.

23) - Apostolic Exhortation "Patores Dabo Vobis," on I will give you Shepherds, Nairobi: Paulines Publications Africa, 25 March 1992.

24) —_ "Message to the European Olympic Athletes," 24 November 1984.

25) — 11th World Youth Day Message," 1996.

26) — 12th World Youth Day Message," 1997.

27) — 16th World Youth Day Message," 2000.

28) — 17th World Youth Day Message," 2002.

29) — 19th World Youth Day Message," 2004.

30) Just for Kids Magazine, "Jesus and Children," Available at: http://www.just4kidsmagazine.com/ rainbowcastle/jesusandchildren.html, Accessed: 10 March 2008.

31) Kelly, Liam. Catechesis Revisisted Handing on Faith Today, London: Darton, Longman and Todd Ltd, 2000.

32) Kilgallen, John J. A Brief Commentary on the Gospel of Mark, New York: Paulist Press, 1989. 
33) Lane, William L. The New International Commentary on the New Testament the Gospel of Mark, Cambridge, UK: William B. Eerdman's Publishing Company, 1974.

34) Lester, Andrew D. Pastoral Care with Children in Crisis, Louisville, Kentucky: Westminster, John Knox Press, 1985.

35) Magante, Antonio. "Scripture Classnotes," 2006/ Academic Year 2006/2007.

36) Mbaegbu, Ifeanyi. He and She Yearning for Love, A Handbook for the Caring Heart, Onitsha: Veritas Printing and Publishing Co. Ltd., 2003.

37) Mbuy, Tatah. H. "The Need for Pastoral Care of Youth in Africa" Interpretation: A Journal of Bible and Theology, Vol. 55, No. 2, April 2001.

38) Mondo, Paulino Twesigye. "Youth in the Heart of the Church:" Steps in a Journey of a Loving Family the Approach of the African Church to Youth from Gauduim et Spes to the Third Millennium," (Bringing the Church to Youth or Youth to the Church), Tangaza Occasional Papers, No. 19, Elena Rastello and Gianni Rolandi, (eds.), Nairobi: Paulines Publications Africa, 2006.

39) Morissette, Herve. Youth Catechesis, Bangalore: The Holy Cross Fathers, 1998.

40) Moschetti, Daniel. "Urban Ministry in Africa," 19-20.

41) Pendawazima, Dietriecu. "The African Family," African Tomorrow, Vol. 1, No. 1, Tanzania: Salvatorian Institute of Philosophy and Theology, 1999.

42) Potworowski, Christophe. "The Attitude of the Child in the Theology of Hans Urs Balthasar," Communio: International Catholic Review, Vol. 22, No. 1, Spring, 1995.

43) Robert K. Martin, 2018 and

44) Rosengren, John. Meeting Christ in Teens, Winona, Minnesota: Saint Mary's Press, 2002.

45) Rowatt, G. W. Adolescents in Crisis A Guidebook for Parents, Teachers, Ministers, and Counsellors, Louisville, London: Westminster, John Knox Press, 2001.

46) Ryan, Thomas. Wellness, Spirituality and Sports, New York: Paulist Press, 1986.

47) Second Vatican Council, "Gravissimum Educationis" on the Decalration on Christian Education, 28 October, 1965.

48) —_ "Sacrosanctum Concilium on the Constitution of the Sacred Liturgy," 4 December, 1963.

49) Singer-Towns, Brian (Gen. Ed.), Vibrant Worship with Youth, 16.

50) Wakefield, Gordon S. (ed.), A Dictionary of Christian Spirituality, Great Britain: SPCK, 1997.

51) Ward, Pete. Youthwork and the Mission of God, Great Britain: SCM Press Ltd., 1983.

52) Whelan, Gerard. "That All May Have Life in Abundance: Theological Foundations for Youth Ministry," Tangaza Occasional Papers, No. 18, Elena Rastello and Gianni Rolandi, eds., Nairobi: Paulines Publications Africa, 2006.

53) Wiafe, Eric Oduro. Arise, Christian Youth! Essays in Christian Formation, pgs 59-60.

54) Winstanley, Michael. Don Bosco's Gospel Way, p. 14.

55) Zenith, "4th World Congress of Families," 15 May, 2007, Available at: http://www.zenith.org, Accessed: 28 May, 2007.

56) Zenith, "Father Cantalamessa on the Family," Rome, 25 December, 2006, Available at: http://www.zenith.org, Accessed: 23 February, 2007.

57) Zenith, "Mexico City," 22 March, 2007, Available at: http://www.zenith.org, Accessed: 28 March, 2007.

58) Zenith, "Vatican City," 21 December, 2006, Available at: http://www.zenith.org, Accessed: 23 February, 2007.

59) Zenith, "Vatican News," 23 February, 2007, Available at: http://www.zenith.org, Accessed: 28 March, 2007. 